
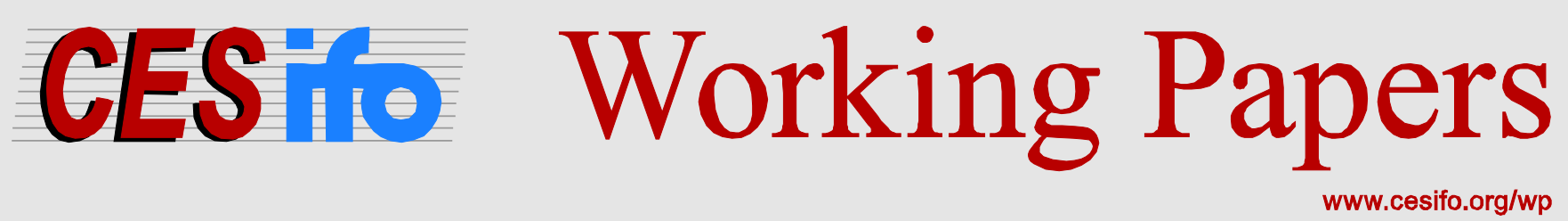

\title{
Central Bank Balance Sheets: Expansion and Reduction since 1900
}

\author{
Niall Ferguson \\ Andreas Schaab \\ Moritz Schularick
}

\section{CESIFO WORKING PAPER NO. 5379 \\ CATEGORY 7: MONETARY POLICY AND INTERNATIONAL FinANCE \\ MAY 2015}

An electronic version of the paper may be downloaded

- from the SSRN website:

- from the RePEc website:

- from the CESifo website: WwW.SSRN.com

Www.RePEc.org

www.CESifo-group.org/wp 


\title{
Central Bank Balance Sheets: Expansion and Reduction since 1900
}

\begin{abstract}
In this paper we study the evolution of central banks' balance sheets in 12 advanced economies since 1900. We find that balance sheet size in most developed countries has fluctuated within rather clearly defined bands relative to output. Historically, clusters of big expansions and contractions of balance sheets have been associated with periods of geopolitical or financial crisis. Relative to the size of the financial sector, central bank balance sheets had shrunk dramatically in the three decades preceding the global financial crisis. By that yardstick, their recent expansion partly marks a return to earlier levels.
\end{abstract}

JEL-Code: E510, E580, N100.

Keywords: central banks, monetary policy, financial history.

Niall Ferguson

Harvard University

Cambridge, MA 02138 / USA

nfergus@fas.harvard.edu
Andreas Schaab

Harvard University

Cambridge, MA 02138 / USA

andreasschaab@college.harvard.edu

\author{
Moritz Schularick \\ Department of Economics \\ University of Bonn / Germany \\ moritz.schularick@uni-bonn.de
}

April 23, 2015 


\section{INTRODUCTION}

Central bank balance sheets around the world expanded dramatically during and after the global financial crisis. While some banks have already successfully wound down their balance sheet operations, others are still engaged in or are only beginning to terminate asset purchase programmes at the time of writing. Some market participants even expect another round of balance sheet expansion by major central banks to ward off deflationary tendencies. Asset purchase programmes nevertheless remain controversial on both sides of the Atlantic (Borio and Disyatat 2009). We are far from having a consensus on exactly how they work, what their long-run consequences may be and how long they should be continued.

In this paper we study the evolution of central bank balance sheets in 12 advanced economies since 1900. We take a closer look at the 20th and 21st centuries' major balance sheet expansions and reductions in order to understand better the implications of large balance sheets and to contextualise what may lie ahead.

To that end we have put together a new dataset on historical central bank balance sheet positions, drawing on numerous historical records and annual central bank reports. Section 2 describes our dataset. In much of this paper, we explore these data and describe the historical facts. We show that, on average, central bank balance sheet size has fluctuated between roughly $10 \%$ and $20 \%$ of gross domestic product (GDP). Only a few important economic and political events have pushed balance sheets outside this range. There are large clusters of expansion-contraction cycles around the World Wars, during the Great Depression and during the recent financial crisis. Both World War I and World War II were followed by deep and protracted periods of balance sheet reductions. But in terms of expansion, only World War II bears comparison with recent experience since 2007. However, the drivers of balance sheet expansions differed in the two cases. While war finance represented a major money supply shock with inflationary consequences, central bank balance sheet expansions in the recent crisis were at least partly reactions to 
a major money demand shock during the crisis.

Our aggregate balance sheet size series displays striking similarities to the aggregate public debt series over the same time period. We infer from this observation that the fiscal and monetary authorities have largely acted in concert when faced with major economic or political crises. This has important implications for today, when it is conventional to emphasise central bank independence and the separation of monetary and fiscal policy-making. History makes clear that the separation of monetary and fiscal policy is a contingent commitment; in times of emergency, the distinction becomes harder to maintain (Goodfriend 2011).

Section 3 also discusses historical trends in the composition of central bank balance sheets. Importantly, we find that, relative to the size of the financial sector, central bank balance sheets and in particular bank deposits at central banks had become very small in the years preceding the global financial crisis. Our long-run data suggest that, to some extent, the post-crisis growth of central bank balance sheets represents a return to levels seen in the 1970s, before the explosive growth of the financial sector. The crucial question is whether or not banks will target permanently higher reserves. A related question is whether or not reserve requirements can and should make a comeback, as proposed by Reinhart and Rogoff (2013).

We also study the relationship between balance sheets and inflation. Analysing low frequency correlations between balance sheet size and inflation, we generally find a positive correlation for most of the 2oth century, as the quantity theory implies. Yet we also show that, in line with the results of Sargent and Surico (2012), the relationship has become weaker in recent decades, thereby providing more nuance to the original results of Lucas (1980).

In Section 4, we take a closer look at a total of 23 large expansions and 17 large contractions in central bank balance sheet size since 1900. We explain our identification methodology and propose a classification framework for expansion episodes. In Section 
5, we discuss what seems to us to be the most instructive expansion and contraction episode in our sample, the period during and after World War II in the United States.

We draw broader lessons from these historical episodes in Section 6, asking how central banks have historically achieved large balance sheet contractions. In particular, we show that most reductions have been realised only relative to GDP. Only very few central banks have normalised their balance sheets after large expansions through nominal reductions in their positions. We then argue that in those instances where central banks did achieve nominal contractions, balance sheet composition was key. In all such cases, banks have successfully unwound their positions by letting short-term lending programmes phase out or by letting short-term assets roll off. We have not recorded a single incident in which a central bank has primarily sold long-term government (or private market) securities to unwind a large expansion in nominal terms.

Section 7 asks just how genuinely "unconventional" recent balance sheet operations have been in historical perspective. Drawing on our new data, we show that, in some respects, the central bank balance sheet expansion occasioned by World War II can be regarded as a precedent. Clearly, the intention of policy in the two cases was quite different. But the functional consequences - in particular the effect on interest rates and the fiscal implications of that effect - had much in common. In that sense balance sheet normalisation poses challenges for central banks (and finance ministries) that are not wholly novel.

In the final section we draw four main conclusions. First, while balance sheets have grown considerably, current levels are neither historically unprecedented nor do they appear unmanageable. In contrast, the recent growth also reflects a catching-up of the size of central banks' balance sheets in relation to a much bigger financial sector. Put differently, central banks' balance sheets had become small relative to financial sector assets and total lending. Like most of the academic community, central banks had largely ignored the build-up of leverage in Western financial systems and the thin foundation 
of liquidity on which the modern financial edifice was built. Since 2008 this trend has been partly reversed and could result in permanently larger balance sheets and higher deposits of commercial banks at central banks.

Second, we find little historical evidence that large balance sheets pose an imminent risk to price stability. The link between balance sheets and inflation was relatively close for most of the 2oth century, but has weakened considerably in the past 35 years. Whether this reflects the increased credibility of central bank independence and price stability policies, or other factors, remains a matter for debate.

Third, studying historical episodes of balance sheet reduction relative to GDP, we find that outright nominal reductions of balance sheets are rare. Historically, reductions have typically been achieved by keeping the growth rate of assets below the growth rate of the economy. The post-World War II unwinding of war finance provides the most telling historical parallel to today's situation. Between 1947 and 1966, the Federal Reserve System's balance sheet shrank by 14 percentage points relative to GDP - a prolonged process of incremental reduction. In the same period, total assets grew from USD 50 billion to USD 68 billion in nominal terms. We conclude with some reflections on the relationship between monetary and fiscal policy. Large-scale purchases of government bonds have implications for government finance, even when government finance is not the primary objective of the purchases, because depressing bond yields reduces government debt service costs, especially when the public debt is relatively high. Ending such purchases may therefore also have fiscal implications, as was true in the late 1940s. An important lesson of that period is that fiscal considerations are not easy to ignore. Although Federal Reserve independence appeared to be restored under the 1951 Treasury-Federal Reserve "Accord", in practice the Federal Reserve remained susceptible to political pressure. History suggests that the threat to long-run price stability is a real if slow-acting one when fiscal deficits are persistent and central bank independence is compromised. 


\section{The DAtA}

Our dataset contains central bank balance sheet data for 12 advanced economies from 1900 to 2012. The countries in our sample are Australia, Canada, Finland, France, Germany, Italy, Japan, Norway, Sweden, Switzerland, the United Kingdom and the United States. After 1999 we consider aggregated balance sheet data for the European System of Central Banks (ESCB) in lieu of the euro area countries Finland, France, Germany and Italy. These data were collected primarily from central banks' annual reports and historical archives. Only a few partial aggregate series existed and had previously been made public.

On the asset side, we have total assets and their decomposition into domestic and foreign assets, gold, as well as government debt (securities and other) held by the central bank. On the liability side, we have total liabilities and their decomposition into domestic and foreign liabilities, notes in circulation, as well as total and bank deposits. Table 1 summarises the data coverage by country and variable. More detailed information about country coverage is provided in the appendix. ${ }^{1}$

Table 1: Dataset

\begin{tabular}{|l|ccccccccc|}
\hline & $\begin{array}{c}\text { Total } \\
\text { assets }\end{array}$ & $\begin{array}{c}\text { Foreign } \\
\text { assets }\end{array}$ & Gold & $\begin{array}{c}\text { Gov. } \\
\text { debt }\end{array}$ & $\begin{array}{c}\text { Total } \\
\text { liabilities }\end{array}$ & $\begin{array}{c}\text { Foreign } \\
\text { liabilities }\end{array}$ & Notes & $\begin{array}{c}\text { Total } \\
\text { deposits }\end{array}$ & $\begin{array}{c}\text { Bank } \\
\text { deposits }\end{array}$ \\
\hline AUS & 102 & 102 & 49 & 102 & 102 & & 75 & 98 & 80 \\
CAN & 79 & 49 & & 79 & 79 & 60 & 79 & 79 & 79 \\
CHE & 107 & 107 & 105 & & 107 & 51 & 105 & 105 & 105 \\
DEU & 96 & 96 & 97 & 97 & 96 & 96 & 97 & 97 & 96 \\
ESCB & 15 & 15 & 15 & 15 & 15 & 15 & 15 & 15 & 15 \\
FIN & 99 & 99 & 99 & 99 & 99 & 99 & 99 & 99 & 99 \\
FRA & 78 & 61 & 78 & 61 & 78 & & 75 & 78 & \\
ITA & 99 & 99 & 99 & 99 & 99 & 99 & 99 & 99 & 99 \\
JPN & 114 & 79 & 55 & 114 & 114 & 35 & 112 & 112 & 80 \\
NOR & 113 & 106 & 99 & 103 & 113 & 59 & 112 & 112 & \\
SWE & 110 & 110 & 108 & 98 & 108 & 74 & 108 & 94 & 108 \\
UK & 114 & & 112 & 114 & 112 & & 112 & 112 & 49 \\
US & 100 & 100 & 100 & 100 & 100 & 98 & 100 & 100 & 100 \\
\hline Total & 1226 & 1023 & 1016 & 1081 & 1222 & 686 & 1188 & 1200 & 910 \\
\hline
\end{tabular}

\footnotetext{
${ }^{1}$ We encountered problems with the decomposition into domestic and foreign currency assets and liabilities for some central banks, especially when statistical publications we drew on did not make the distinction and we were unable to obtain relevant historical sources. The decomposition of the domestic portfolio into holdings of government debt and other securities was not universally available either.
} 
We draw on work by Schularick and Taylor (2012) and Jordá, Schularick and Taylor (2013) and use their dataset of historical macroeconomic variables from 1870 to 2012. Their dataset includes annual figures for credit aggregates, interest rates and equity prices, as well as a large number of "real" variables for all 12 countries for the entire 2oth century. In our analysis we study balance sheet size relative to GDP. The key variable of interest in subsequent sections will be total assets over GDP, which we view as the most helpful measure of central bank balance sheet size. Whenever we subsequently refer to changes in the size of a central bank's balance sheet, we should be understood as referring to percentage point changes of total assets relative to GDP. We shall explicitly point out when we are referring to changes in nominal asset holdings. We report summary statistics and our number of observations, as well as the number of years with positive and negative growth for this variable in Table 2.

Table 2: Summary statistics for changes in central bank balance sheet relative to GDP

\begin{tabular}{|l|cccccccc|}
\hline & Mean & Median & Standard & Min & Max & $\begin{array}{c}\text { Number of } \\
\text { observations }\end{array}$ & $\begin{array}{c}\text { Years } \\
\text { positive }\end{array}$ & $\begin{array}{c}\text { Years } \\
\text { negative }\end{array}$ \\
\hline AUS & -0.23 & -0.03 & 1.69 & -9.02 & 3.36 & 89 & 43 & 46 \\
CAN & -0.13 & -0.09 & 0.43 & -1.51 & 1.38 & 66 & 21 & 45 \\
CHE & 0.51 & -0.18 & 3.59 & -7.91 & 19.85 & 104 & 51 & 53 \\
DEU & 0.03 & 0.04 & 0.89 & -2 & 2.92 & 74 & 40 & 34 \\
ESCB & 0.81 & 0.37 & 3.43 & -7.43 & 7.17 & 14 & 9 & 5 \\
FIN & -0.06 & 0.03 & 2.69 & -13.16 & 11.93 & 98 & 50 & 48 \\
FRA & -0.24 & -0.24 & 1.87 & -7.34 & 7.43 & 74 & 32 & 42 \\
ITA & -0.02 & 0.07 & 2.67 & -13.77 & 6.82 & 98 & 54 & 44 \\
JPN & 0.31 & 0.06 & 2.54 & -8.24 & 13.49 & 102 & 52 & 50 \\
NOR & -0.69 & -0.32 & 3.39 & -15.91 & 12.84 & 104 & 41 & 63 \\
SWE & 0 & -0.25 & 2.59 & -13.01 & 15.07 & 95 & 41 & 54 \\
UK & 0.14 & 0 & 1.51 & -4.46 & 10.54 & 111 & 54 & 57 \\
US & 0.18 & -0.1 & 1.4 & -3.79 & 8.86 & 97 & 40 & 57 \\
\hline
\end{tabular}

These summary statistics show that countries have, on average, experienced roughly equal numbers of years with balance sheet growth and decline relative to GDP. We also observe cross-country differences in the variability of balance sheet size over time. The Bank of Canada stands out with the lowest variation in its total asset holdings over time. The Swiss National Bank has the highest standard deviation; fluctuations of foreign asset holdings in the 1930 s played an important role here. The Swiss National Bank also experienced the largest one-year growth in balance sheet size relative to GDP, with a near 20 percentage point increase in 1936 when the country left the gold standard. The Norges 
Bank undertook the deepest one-year contraction after World War II in 1947.

\section{Central Bank Balance Sheets Since 1900}

In this section, we report a series of historical facts about the evolution of central bank balance sheets in the aggregate during the past century. The history of central bank balance sheets since 1900 has been governed by a handful of important events.

We start by plotting the annual mean and median aggregate balance sheet size relative to GDP for all countries and for the full time-period in Figure 1. The graph shows that, until recently, and with the exception of World War II, central bank balance sheets have ranged, on average, between $10 \%$ and $20 \%$ of GDP. The most striking feature in the data are two large spikes in aggregate balance sheet size, during World War II and since 2007, as well as a third smaller spike around World War I. It is true for most central banks that balance sheet size has remained within a rather clearly defined band, moving outside this band during only a few episodes.

Figure 1: Balance sheets relative to GDP

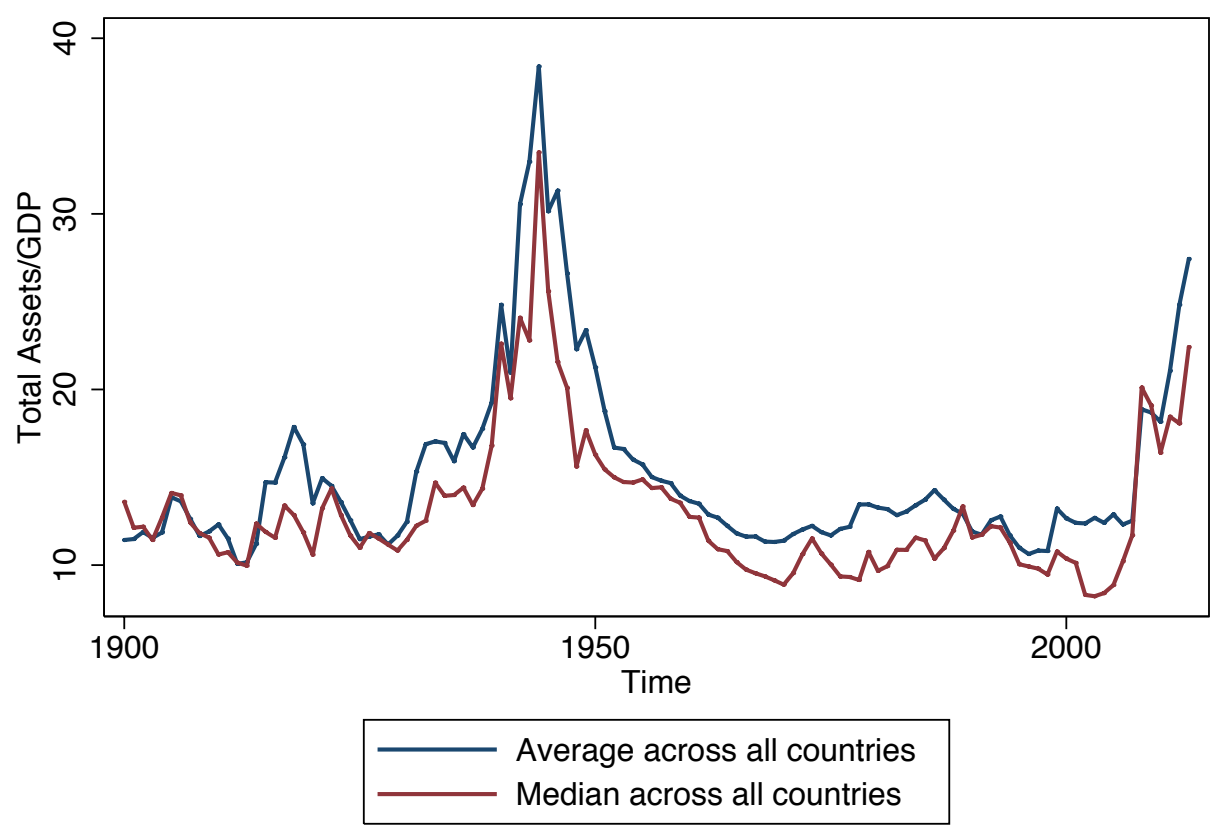

One of the most interesting historical facts visible here is the prolonged balance sheet reduction that followed World War II. Shared by all central banks whose balance sheets 
were not destroyed during the war or affected by post-war currency reforms, this episode began in 1946 and lasted for some countries until the late 1960s. On average, balance sheet size normalised to pre-war levels, with an overall decline of almost 20 percentage points relative to GDP. From the late 196os balance sheets stabilised, on average, at around $10 \%$ of GDP. The graph also makes clear that central bank balance sheets today have reached a level that was altogether unparalleled in the 2oth century except during World War II. The eight central banks in our sample and the euro area central banks experienced a significant increase in their balance sheets after 2007. On average, balance sheets have grown by almost 20 percentage points relative to GDP. The expansion leading up to and during World War II was also around 20 percentage points, though a direct comparison of magnitudes is difficult as we lack data for some countries during the war.

Another important insight emerges when we plot the average annual public debt-toGDP ratio over the same time period in the lower panel of Figure 2. The upper panel again plots average balance sheet size across central banks as well as their holdings of government debt. The co-movement between these series is striking. Public debt has exhibited the same patterns since 1900 that we described in the previous paragraph. Its fluctuations have been larger in magnitude, ranging from a minimum of $30 \%$ to a maximum of almost $150 \%$ of GDP. The public debt expansion during World War I lagged behind that of central bank balance sheets on average, and public debt did not normalise fully after the war. Central bank balance sheet size increased by relatively more during the Great Depression. Both series register an unprecedented rise during World War II and feature the same contraction pattern after the war. The most obvious deviation in the series' co-movement is that public debt, on average, gradually increased from the mid-1970s onwards while central banks' balance sheet size remained relatively stable. We conjecture that growing political and intellectual support for central bank independence during the time period may help explain this finding. Finally, while central bank balance sheets have experienced an expansion since 2007 that is only paralleled by that during World War II, public debt has not risen quite as strongly in relative terms. 
Figure 2: Government debt held by central bank and public debt relative to GDP
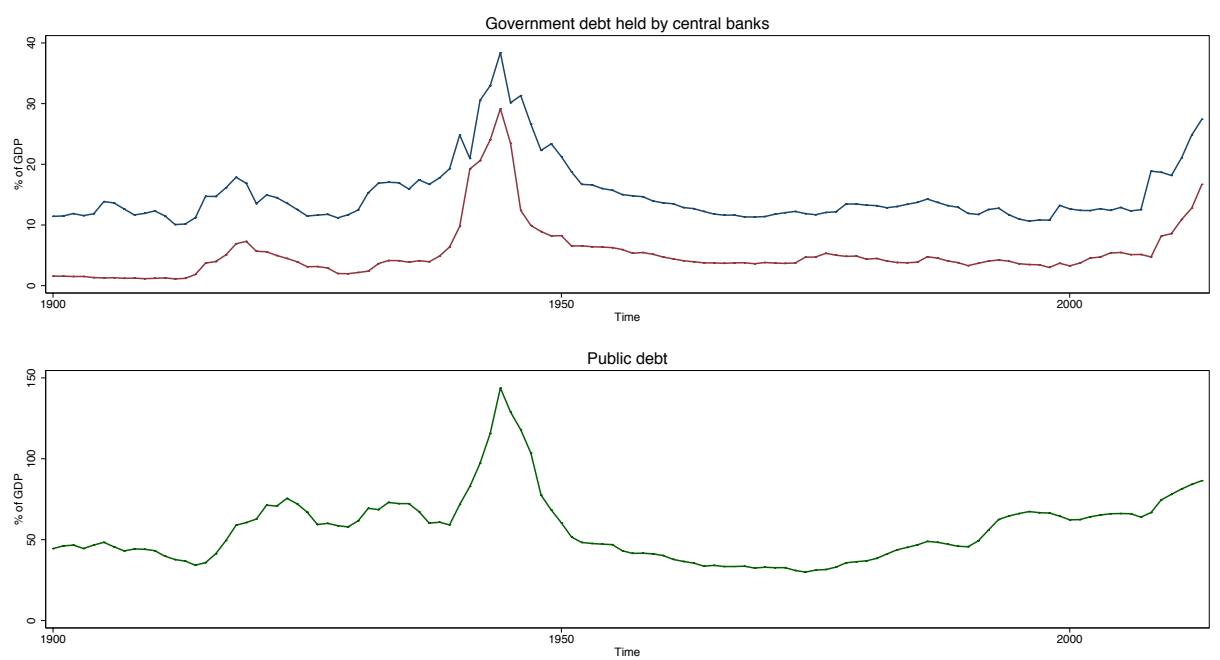

Average aggregate total assets/GDP

Average aggregate gov debt held by CB/GDP

Average aggregate public debt/GDP ratio

\subsection{Balance Sheet Composition Over Time}

We continue our discussion of aggregate balance sheet trends with the composition of balance sheets over time. We will first look at foreign assets and government debt holdings before turning to the liability side to study the evolution of commercial bank reserves.

\subsubsection{Foreign Assets}

Figure 3 plots aggregate foreign assets as a share of total balance sheet size. The first line reports this average across central banks, counting gold as a foreign asset. Under the pre-World War I gold standard, foreign assets accounted, on average, for a higher share of central bank balance sheet size than at any other point before the 1990s. The World Wars were low points of foreign asset holdings. Central banks rebuilt foreign assets after 1950. During the financial crisis central banks amassed domestic assets in 2008 as part of their policies to restore financial market functioning. 
Figure 3: Foreign asset holdings as share of total balance sheets

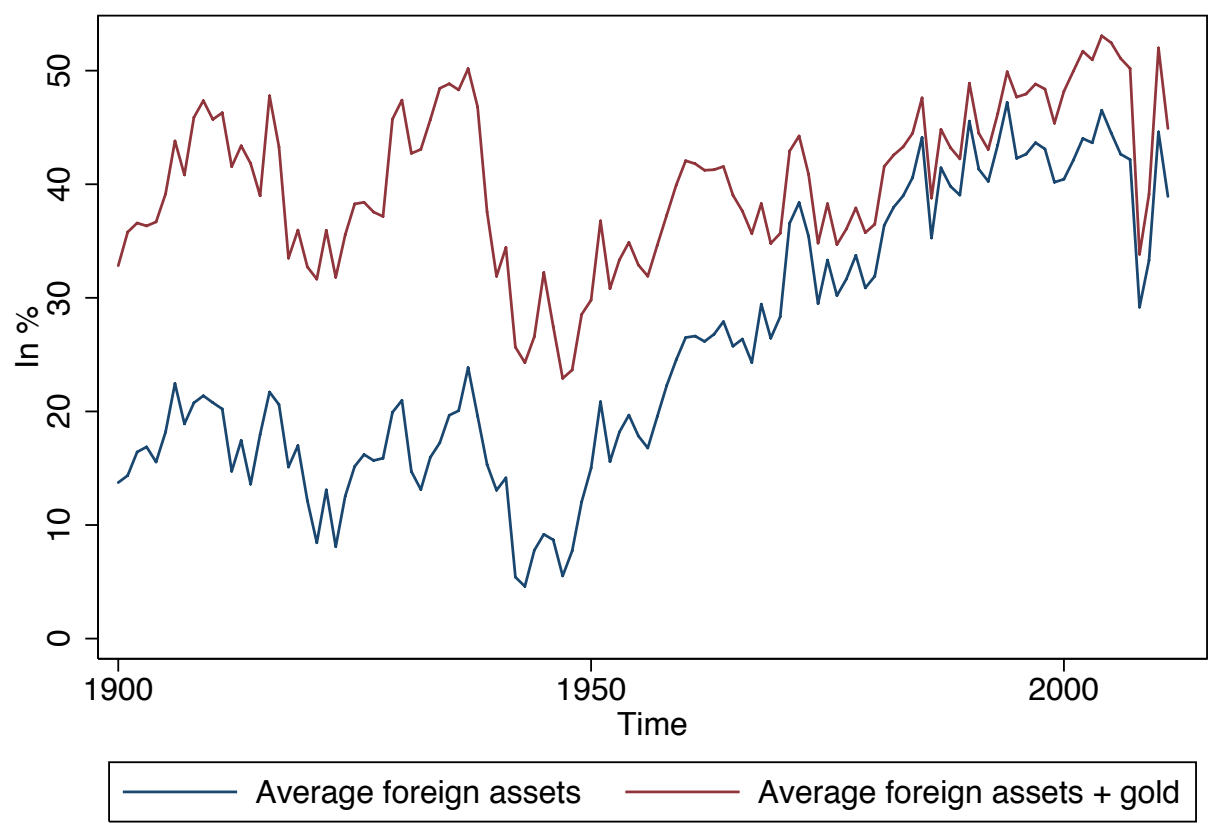

\subsubsection{Government Debt Holdings}

Next we look at central banks' holdings of public debt. Figure 4 plots the average government debt holdings across central banks as a share of total balance sheet size. What is evident is that supporting governments' war finances became a dominant function of central banks during the World Wars. Government debt holdings as a share of total assets did not normalise to pre-1939 levels during the widespread balance sheet reduction episode of the 1950s and 1960s. The pronounced decline in 2008 was due to central banks' emergency measures during the heat of the crisis. After lender of last resort policies were phased out, some central banks substituted government securities and other government-guaranteed assets. Government debt and government-guaranteed assets today again account for as large a share of central bank balance sheet size as they did during World War II. 
Figure 4: Government debt holdings as share of total balance sheet

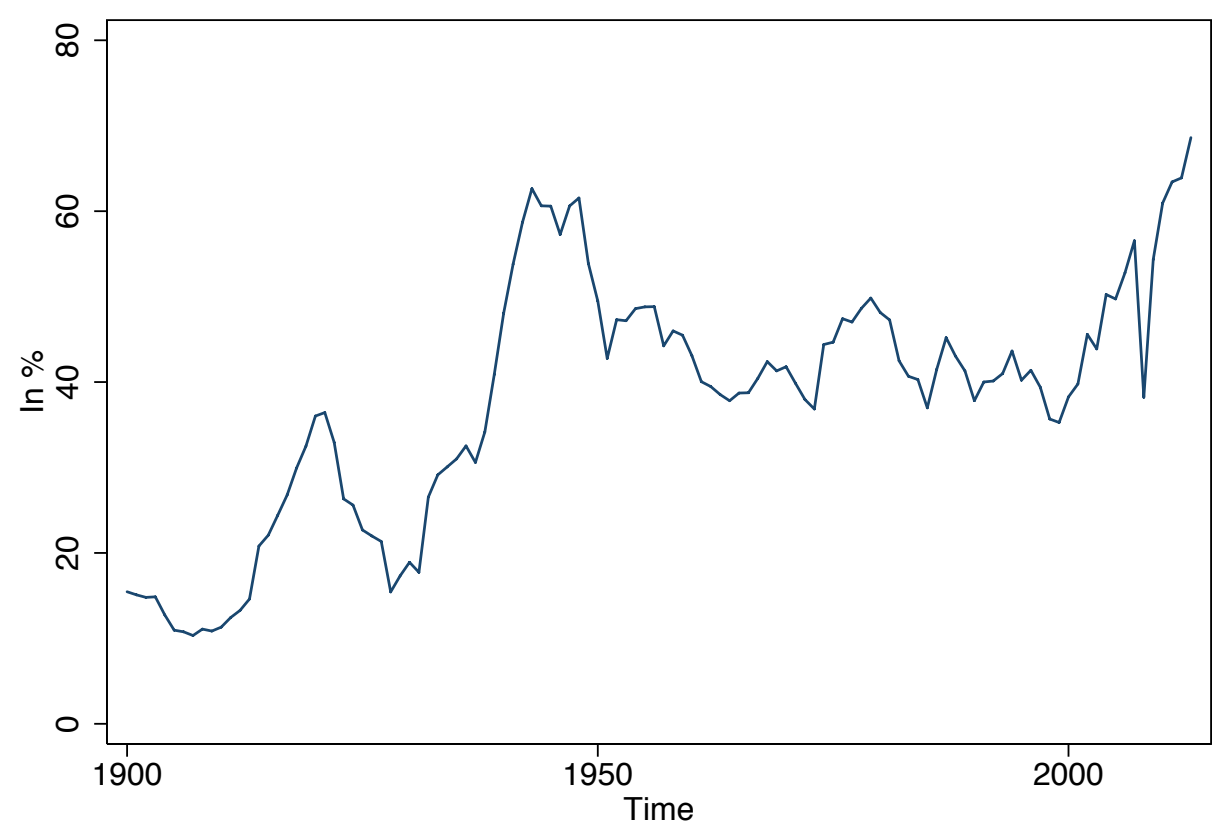

\subsubsection{Commercial Bank Reserves}

In Figure 5, we plot total deposits and bank deposits as a share of total central bank liabilities. The most striking observations are the gradual decline of deposits after 1980 and the sudden spike during the financial crisis. Especially large-scale asset purchases from 2009 onwards have increased the share of bank deposits in total central bank liabilities. Yet the long-run perspective delivers an additional important insight: despite the large expansion after the global financial crisis, the share of bank deposits in total liabilities is only now back to where it was in 1980, before the explosion of the size of the financial sector in the last three decades, documented recently by Philippon and Reshef (2013) as well as Schularick and Taylor (2012). From this angle, the growth of reserve liabilities of central banks' in the past few years can be thought of as a normalisation and a return to higher and potentially safer levels of bank deposits that prevailed before 1980.

We continue this line of inquiry in Figure 6, which shows average commercial bank reserves held with central banks relative to total bank lending, i.e. relative to the size of the financial sector since 1950. Comparing the two figures, we observe the same patterns 
in recent decades: the volume of bank deposits declined rather markedly relative to reserves held and then spiked after the financial crisis back to levels last seen in the 1970s.

Figure 5: Deposits with central bank as share of total balance sheet

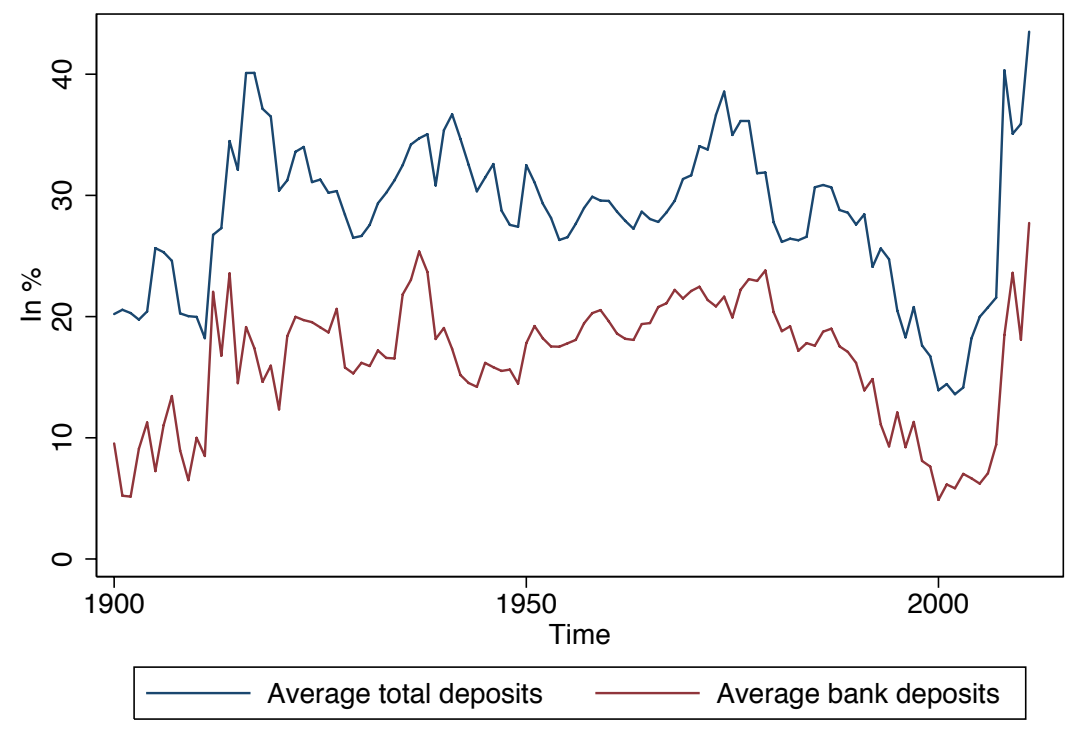

Figure 6: Commercial bank reserves at central bank relative to total bank lending

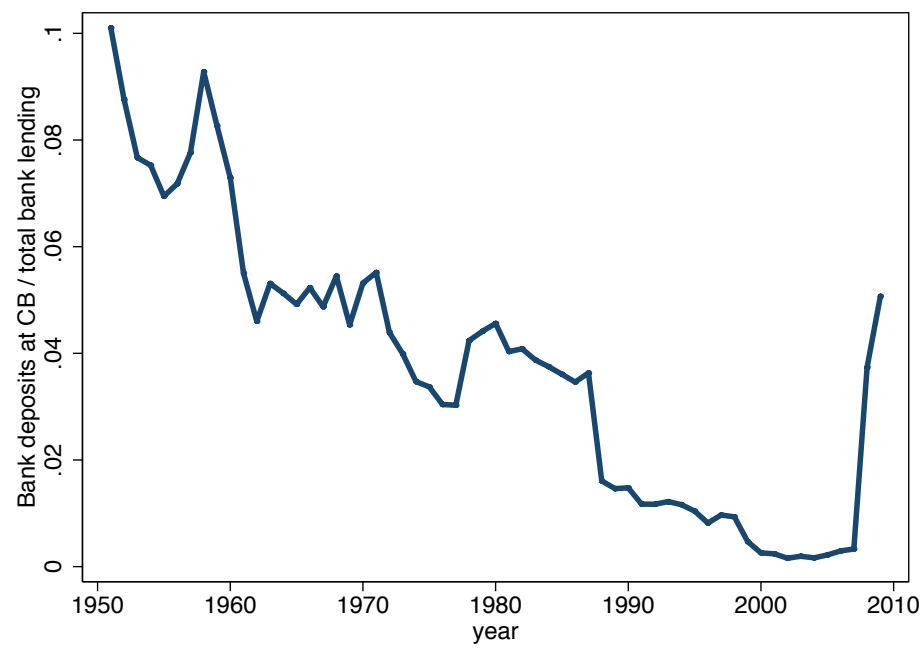




\subsection{Balance Sheets, Broad Money and Bank Lending}

In this section, we take a closer look at the evolution of central bank balance sheets and the growth of the financial sector. Figure 7 plots the median balance sheet size across central banks relative to the money supply and relative to total loans. This casts balance sheet size relative to the size of the financial sector rather than the real economy.

Figure 7: Balance sheet assets relative to financial sector lending and M2

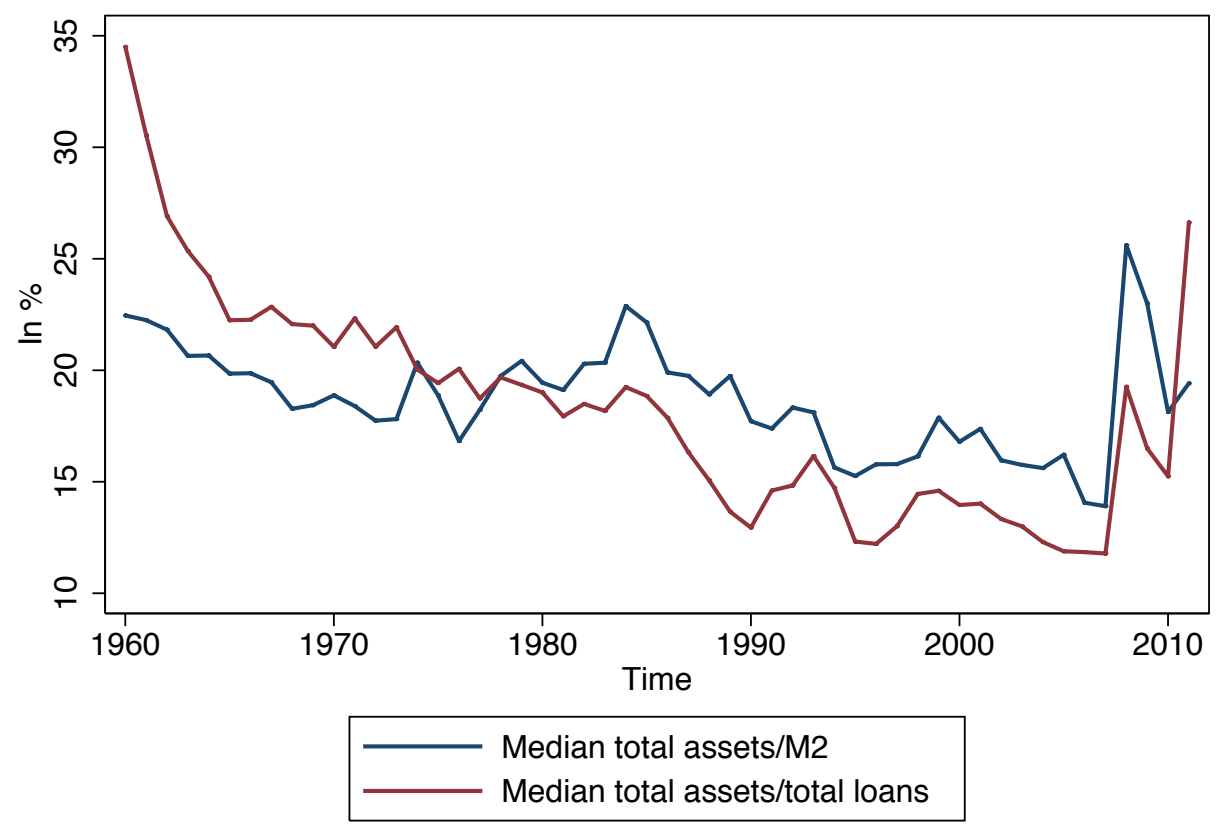

The interesting historical insight here is that, scaled by the size of the financial sector, the recent expansion of central bank balance sheets appears more like a return to previous, potentially safer levels of the ratio of central bank money to financial sector assets. By contrast, what may need explanation is the shrinking size of central bank balance sheets relative to financial sector assets between 1980 and 2007. This rapid increase in the size of the financial sector, a process sometimes dubbed "financialisation", has attracted considerable attention over the last years. It is reflected in the rising income share of finance (Philippon 2012; Greenwood and Scharfstein 2013; Philippon and Reshef 2013), the growth of the balance sheets of private financial intermediaries (Jordá, Schularick and Taylor 2013) and has been interpreted as an indicator of excessive risk taking (Admati and Hellwig 2013; Aikman, Haldane, and Nelson forthcoming). Our data demonstrate that, 
relative to the rapid growth of finance, central bank balance sheets had become rather small by historical standards. The recent increase merely takes us back to the levels seen before the great wave of financial sector growth in the early 1980s. Some of the recent increase in the size of central bank balance sheets might well be permanent if, as seems likely, we do not see a return to the thin liquidity holdings of the pre-crisis years.

\subsection{Balance Sheets and Inflation}

The inflation risk stemming from central bank balance sheet expansion and potential monetisation of government debt figures prominently in today's public debate (see, for example, Reynard 2012). What can the macroeconomic history of the 2oth century tell us about the link between central banks' balance sheets and inflation?

The approach taken here is inspired by Lucas's (1980) test of the quantity theory of money. Lucas filtered time series on money growth and inflation in order to remove shortrun business cycle fluctuations and extract the underlying low frequency correlations between money and inflation. If the quantity theory of money holds, a change in the growth rate of money should induce an equal change in the rate of price inflation. In his original exercise, Lucas found evidence for such a correlation by looking at slow moving averages of money growth and inflation.

In recent work, Sargent and Surico (2012) have applied Lucas's method to US data spanning the whole 2oth century, pointing to the instability of the relationship between money growth and inflation in recent decades. To be precise, the correlation between money growth and inflation breaks down after 1980. The authors explain this divergent result with the change in the monetary policy framework, in particular to the establishment of central bank independence and a credible commitment to keep inflation low.

In this section, we apply the same approach to study the relationship between changes in central bank balance sheets and inflation. ${ }^{2}$ Clearly, there are good reasons to assume that the association between central bank money and inflation is looser than the correlation between broader monetary aggregates and inflation. Yet to the degree that central bank actions affect monetary conditions and the money creation of commercial banks more

\footnotetext{
${ }^{2}$ Lucas (1980) proposes smoothing the log-differenced time series of money and price level using the following filter: $x(\beta)_{t}=\alpha \sum_{-n}^{n} \beta^{k} x_{t+k}$, with $\alpha=(1-\beta) 2 /((1-\beta 2-2 \beta n+1(1-\beta))$. We set $n=4$ and $=0.95$. In practice, the results do not depend on the choice of the filter, as also noted by Sargent and Surico (2012).
} 
broadly, such estimations could still be informative. We use a window of four years on either side to calculate the low frequency correlation between balance sheet changes and inflation. In the spirit of Sargent and Surico (2012) we first look at the 1950 - 1980 period, and then in greater detail at the $1980-2004$ period. Note that we exclude the post-2008 crisis years so that the results are not distorted by the recent balance sheet operations.

Figure 8 shows the slow moving correlation between central bank balance sheet growth and inflation from 1950 to 1980. As many economists would expect, the correlation is positive in almost all countries. But it is also much closer in some countries than in others. Such differences potentially reflect differences in the inflation fighting credentials of the monetary authorities. If the public had no doubt that the central bank would respond strongly to emerging inflationary pressures and not allow persistent increases in money growth, we would expect the relationship between the two variables to have been weaker. It is striking that before 1980 only the Deutsche Bundesbank seems to have achieved such credibility. After 1980, however, the correlations break down in many countries, confirming the findings obtained by Sargent and Surico (2012) for broader monetary aggregates.

Figure 8: Central bank balance sheet growth and inflation, $1950-1980$
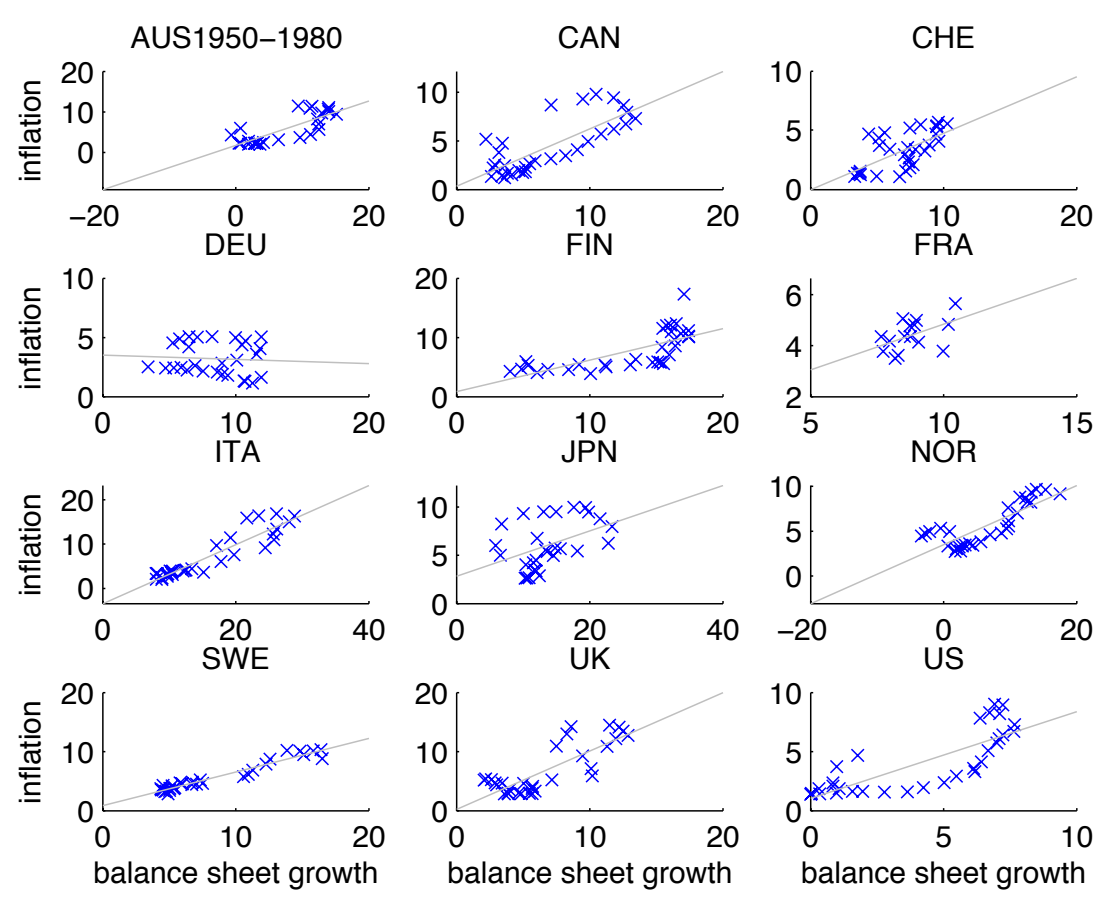
Figure 9: Central bank balance sheet growth and inflation: 1980 - 2004
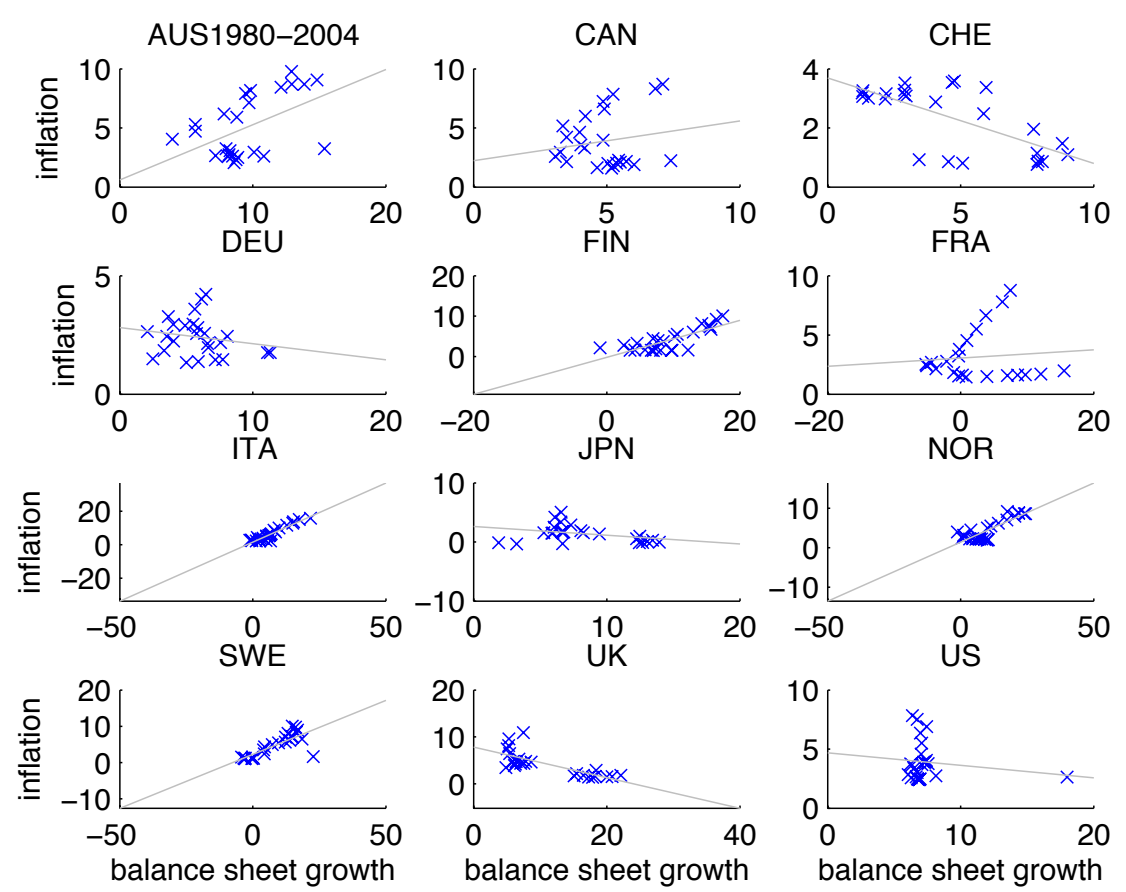

Even before the 2008 crisis, then, the relationship between balance sheet size and inflation was loose at best in many countries. A potential explanation for weakening correlations could be that central banks in advanced economies had indeed made considerable credibility gains in recent decades, anchoring the inflation expectations of the public. An important implication may be that there is little to fear from recent balance sheet expansions as long as the underlying commitment to react to incipient inflationary pressures is not called into question. At the very least, the data confirm that central banks enjoy considerable short-term flexibility to manage their balance sheets without automatically triggering inflation. 


\section{Large Balance Sheet Expansions and Reductions in the 2OTH}

\section{CENTURy}

In this section, we identify the largest central bank balance sheet expansions and contractions during the 2oth century. We identify a total of 23 expansions and 17 contractions across 12 central banks since 1900. Table 3 lists these events. The variable on which we focus is total assets relative to GDP, and we define events as large changes in this ratio. We employed a straightforward identification technique, following two simple steps:

1. As a first step, we coded any country-year as a major balance sheet expansion or contraction year if balance sheet size relative to GDP expanded or contracted by more than 1o percentage points, relative to any previous year in a five-year window. ${ }^{3}$

2. Once an event was identified as expansion or contraction, we determined start and end dates based on historical sources. Wherever warranted, we increased the time window to include episodes that we deemed important based on our reading of the historical sources, but which were not picked up by this arguably crude algorithm. Our only such addition was the Federal Reserve's balance sheet reduction between 1947 and 1966 . While this contraction exceeded the threshold of $10 \%$, it took somewhat longer to be completed.

Table 3 provides information about the episodes' magnitude and length. "Amplitude" reports the cumulative change in balance sheet size relative to GDP, and "duration" the number of years between an episode's start and end dates.

We plot the incidence of large balance sheet expansions and contractions in Figure 10. Consistent with our discussion in the previous section, the graph identifies a few large clusters in the incidence of expansions and contractions: the expansion-contraction cycles during the World Wars, the Great Depression, and the recent financial crisis. In World War I, the central banks of Finland, France and Italy experienced large balance sheet expansions and subsequent contractions. These reductions lasted into the 1920 . Two central banks recorded significant expansions during the Great Depression: those of Switzerland and France. Both countries were among the last to abandon the gold

\footnotetext{
${ }^{3}$ The results generated by a cut-off of 10 percentage points correspond closely to what we would have identified as large balance sheet expansions or contractions from a purely historical perspective.
} 
Table 3: Major expansion and contraction episodes

\begin{tabular}{|ccc|ccc|}
\hline Expansions & Amplitude & Duration & Contractions & Amplitude & Duration \\
\hline CHE 1930 & 31.71 & 9 & AUS 1951 & -22.63 & 10 \\
CHE 1996 & 11.36 & 5 & CHE 1939 & -11.24 & 3 \\
CHE 2008 & 60.91 & 5 & FIN 1919 & -19.01 & 3 \\
ESCB 2007 & 17.9 & 6 & FIN 1945 & -18.77 & 4 \\
FIN 1915 & 16.6 & 4 & FRA 1919 & -17.92 & 8 \\
FIN 1938 & 10.55 & 4 & FRA 1945 & -44.88 & 5 \\
FRA 1914 & 23.55 & 5 & FRA 1980 & -18.65 & 17 \\
FRA 1927 & 19.55 & 6 & ITA 1920 & -14.8 & 7 \\
FRA 1940 & 75.43 & 5 & ITA 1945 & -24.18 & 3 \\
FRA 1973 & 16.54 & 6 & JPN 1908 & -12.51 & 7 \\
ITA 1914 & 14.62 & 6 & JPN 2006 & -11.6 & 2 \\
ITA 1941 & 16.96 & 4 & NOR 1947 & -65.5 & 11 \\
ITA 1974 & 10.57 & 3 & NOR 1987 & -18.23 & 6 \\
JPN 1905 & 13.49 & 1 & NOR 2009 & -10.64 & 4 \\
JPN 1939 & 20.45 & 6 & SWE 1993 & -14.08 & 5 \\
JPN 1997 & 20.16 & 9 & SWE 2010 & -13.01 & 1 \\
JPN 2009 & 14 & 5 & USA 1947 & -13.22 & 20 \\
NOR 1940 & 75.4 & 7 & & & \\
NOR 1983 & 23.39 & 4 & & & \\
SWE 1991 & 11.8 & 2 & & & \\
SWE 2008 & 16.04 & 2 & & & \\
GBR 2008 & 22.97 & 5 & & & \\
USA 2008 & 14.36 & 6 & & & \\
\hline \hline
\end{tabular}

standard in the late 1930s, and their central banks were on the receiving end of global capital flows in the first years of the Great Depression.

Every central bank for which we have data on balance sheet size relative to GDP in the 1940s recorded a major expansion during World War II, with a few exceptions. World War II was followed by a protracted period of balance sheet reduction. In some countries, this episode lasted until the late 1960s. Six central banks in total experienced large balance sheet contractions during those years. Six of the 17 largest balance sheet reduction episodes we identify since 1900 occurred immediately following World War II. Three episodes lasted ten or more years, with the Federal Reserve System experiencing the longest contraction in our sample. The Banca d'Italia, the Bank of Finland, and the Banque de France managed to unwind their positions relatively quickly, taking three, four and five years, respectively. 
Figure 10: Tally of central bank expansion and contraction episodes

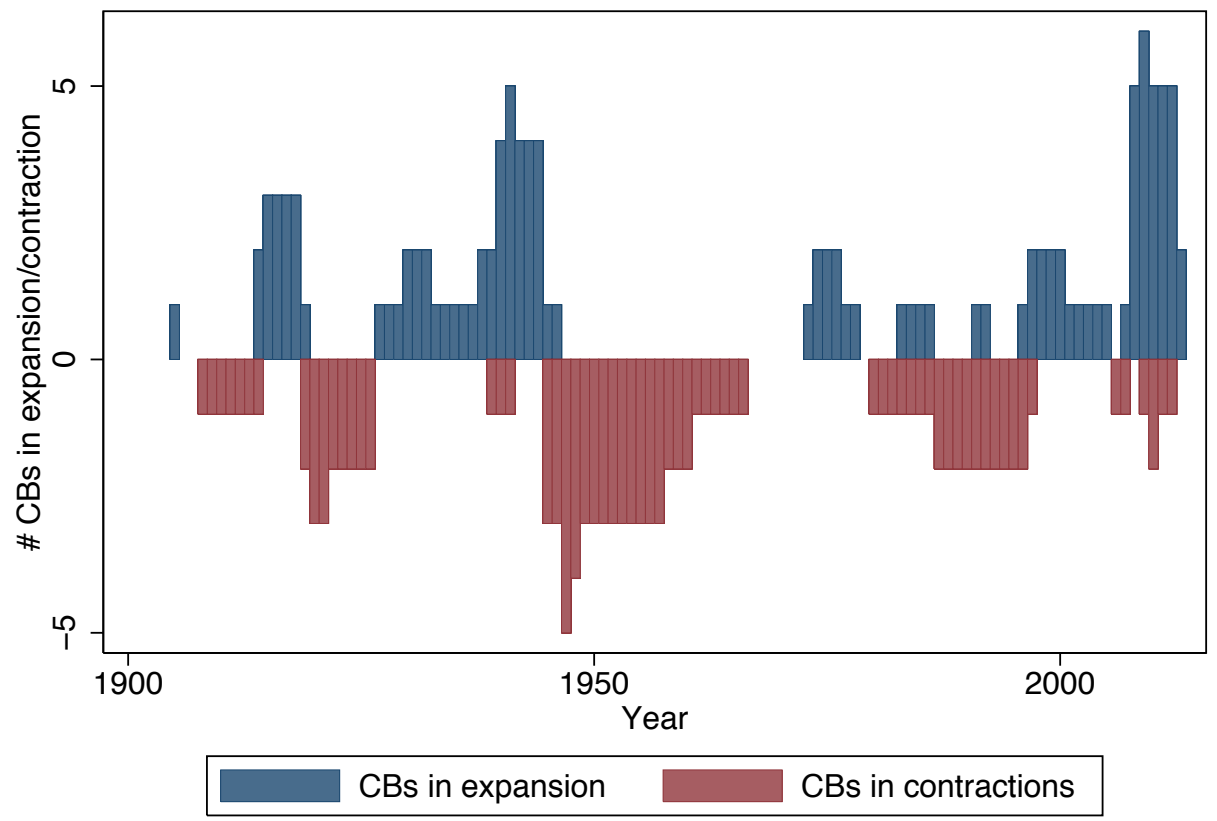

The most recent balance sheet expansions during the global financial crisis exceed in both magnitude and incidence all previous expansion episodes except those of World War II. Reporting data for the ESCB instead of individual euro area central banks after 1999, we find that six out of nine central banks in our sample significantly increased their balance sheet positions. The year 2008 alone thus witnessed over a quarter of all the largest expansion episodes since 1900. The exceptions were the central banks of Australia, Canada and Norway. ${ }^{4}$

Figure 1o points to a second, more moderate episode of balance sheet contractions in the 1980s and 1990s. However, we do not apply the label "cluster" here as not all of these episodes were related. Some central banks, especially those of France and Switzerland, had run up sizable balance sheet positions during the tumultuous 1970 and began reducing these after the second oil crisis. The Banque de France shrank its balance sheet by almost 19 percentage points relative to GDP over 17 years. In addition, Sweden and Norway underwent expansion-contraction cycles in the late 1980s and early 1990s during the Scandinavian and ERM crises. Together with Finland, these countries experienced

\footnotetext{
${ }^{4}$ For Norway, we report total financial assets after 1996 and exclude the Norges Bank's investment position in Norway's Petroleum Fund.
} 
both banking and currency crises during this period. Balance sheet reductions have varied in duration. Japan and Sweden achieved the shortest balance sheet reductions in 2006 and 2010, respectively. In both cases, the central bank let large amounts of short-maturity assets roll off, without changing the composition of longer-term assets significantly. However, most central bank balance sheet reductions have historically been prolonged affairs. Many of the longest balance sheet reductions followed the World Wars, with the post-World War II contraction cluster featuring the longest and deepest episodes. Of all episodes in our sample, the government debt finance expansions of World War II have taken by far the longest to unwind.

One can distinguish between four types of central bank balance sheet expansion. In our view, the terms "conventional" and "unconventional" are not very useful if we are to understand the implications and likely consequences of large-scale balance sheet expansions. Such terms are unhistorical, as the conventions they imply are of relatively recent origin and certainly did not apply to central banking in the 1940s and 1950s. We argue that the composition of the central bank's balance sheet matters a great deal when considering potential normalisation strategies. We also argue that this composition can quite often be traced back to the policy intent of the balance sheet operation, a metric that is more easily gauged by the historian. In economic terms some of the major expansions represent clear money supply shocks driven by war finance. Other episodes, especially those taking place in times of financial crisis, can be described as expansions that accommodate major money demand shocks. ${ }^{5}$

We classify expansion episodes by the underlying motivation, or intent, of balance sheet policy. We identify four distinct categories:

3. Foreign exchange and balance of payments (FX): This category describes all balance sheet operations carried out with the explicit goal of supporting the exchange rate regime. During the 1930s, for example, central banks adhering to the gold standard experienced fluctuations in the size of their balance sheets due to balance of payments dynamics. Under a fixed rate regime or peg, the balance sheet is subordinate to balance of payments dynamics.

4. Government financing (GF): Episodes during which the central bank had the explicit intention of financing government expenditure fall into this category. Such balance

${ }^{5}$ We are indebted to Paul Tucker for pointing this out. 
sheet operations represent a shift in monetary regime, whereby the fiscal authority becomes the dominant one. During much of the period covered by our dataset, the idea of central bank independence was far from dominant amongst either economic theorists or central bankers. Especially during the World Wars, most central banks were dominated by the fiscal authority and supported their governments' war expenditures. This should not surprise us, given that so many modern central banks - notably the Bank of England - were established precisely to perform this function.

5. Lender of last resort and market functioning (LLR): For the purpose of our analysis, we combine lender of last resort policy with balance sheet operations aimed at restoring credit intermediation and market functioning. The former type of central bank policy aims to provide liquidity and support a single firm or set of counterparties, usually financial institutions. The latter type is targeted at entire market segments, rather than individual market participants. Lender of last resort activity may be considered a subset of the set of policies aimed at restoring market functioning in a broader sense, as the latter can also include outright purchases of securities and other assets. To simplify nomenclature, we subsequently refer to this third category simply as LLR policy.

6. Demand stabilisation (DS): We group large-scale balance sheet operations in which the central bank engages in outright asset purchases with the specific aim of stimulating aggregate demand in this final category. The distinction between DS and LLR measures is twofold. Demand stabilisation policies directly aim at reducing yields and borrowing rates in certain market segments, beyond merely restoring their functioning. Secondly, they have often involved outright purchases of longerterm assets, whereas LLR policy has tended to emphasise shorter-term liquidity provision (see International Monetary Fund 2013).

This classification resonates roughly with the distinction between credit easing and quantitative easing stressed by the Federal Reserve to differentiate its first round of largescale asset purchases from Japan's policy programme after 2001. It contrasts slightly with classifications proposed elsewhere in the literature. ${ }^{6}$ Table 4 again lists large expansion episodes, this time classifying each by type. We focus on what we perceive as the primary

\footnotetext{
${ }^{6}$ For example, Borio and Disyatat (2009).
} 
policy intent behind episodes. In cases where balance sheet policy really did fit more than one type, we assign them to multiple categories. We note that the policy intent behind a balance sheet expansion sometimes changed over time. As most balance sheet reductions have historically followed immediately after expansions, it will subsequently prove helpful to think about them in terms of what caused the initial increase in the balance sheet size.

During most of our sample period, central banks operated under pegged or fixed exchange rate regimes. Most of the balance sheet size fluctuations during this period were driven by balance of payments dynamics, whereby the central bank bought and sold either gold or foreign assets to maintain a desired exchange rate. Especially during the early part of the Great Depression, balance sheet size fluctuations were primarily due to policy motivated by the gold standard regime. As already noted, Switzerland and France both stayed on the gold standard until the late 1930 and accumulated vast gold reserves during that time. Government debt finance episodes are exclusively associated with large wars in our sample. The Russo-Japanese War of 1904-05 prompted an expansioncontraction episode at the Bank of Japan. And, as we have already pointed out in our discussion of aggregate trends, both World Wars witnessed a widespread expansion of central bank balance sheets. We identify the subsequent balance sheet contractions uniformly as government finance episodes. All central banks in our sample whose balance sheets remained functional during the war began shedding government debt in the late 1940s, in a gradual and prolonged process that lasted until the late 1960s. Since then, there has been no major episode of government debt finance in our sample.

Foreign exchange and government finance episodes have occurred less frequently since 1970. For one thing, most countries in our sample adopted floating exchange rates during this period. For another, central banks in general were affected by the gradual intellectual paradigm shift towards both central bank independence and inflation targeting. An additional point is that, after Vietnam, the wars fought by the countries in our sample were significantly smaller in their scale and relative cost. 
Table 4: Type of balance sheet expansion

\begin{tabular}{|c|c|c|c|c|}
\hline Expansion & FX & GF & LLR & DS \\
\hline CHE 1930 & $x$ & & & \\
\hline CHE 1996 & $x$ & & & \\
\hline CHE 2008 & $x$ & & $x$ & \\
\hline ESCB 2007 & & & $x$ & \\
\hline FIN 1915 & & $X$ & & \\
\hline FIN 1938 & & $X$ & & \\
\hline FRA 1914 & & $X$ & & \\
\hline FRA 1927 & $x$ & & & \\
\hline FRA 1940 & & $X$ & & \\
\hline FRA 1973 & $X^{*}$ & & & \\
\hline ITA 1914 & & $x$ & & \\
\hline ITA 1941 & & $x$ & & \\
\hline ITA 1974 & $X^{*}$ & & & \\
\hline JPN 1905 & & $X$ & & \\
\hline JPN 1939 & & $x$ & & \\
\hline JPN 1997 & & & & $x$ \\
\hline JPN 2009 & & & & $x$ \\
\hline NOR 1940 & & $X$ & & \\
\hline NOR 1983 & $x$ & & & \\
\hline SWE 1991 & $x$ & & $x$ & \\
\hline SWE 2008 & & & $x$ & \\
\hline UK 2008 & & & $x$ & $x$ \\
\hline US 2008 & & & $x$ & $x$ \\
\hline
\end{tabular}

*Our historical research on these episodes is ongoing and classifications are provisional. 
Figure 11: Expansions and contractions by type

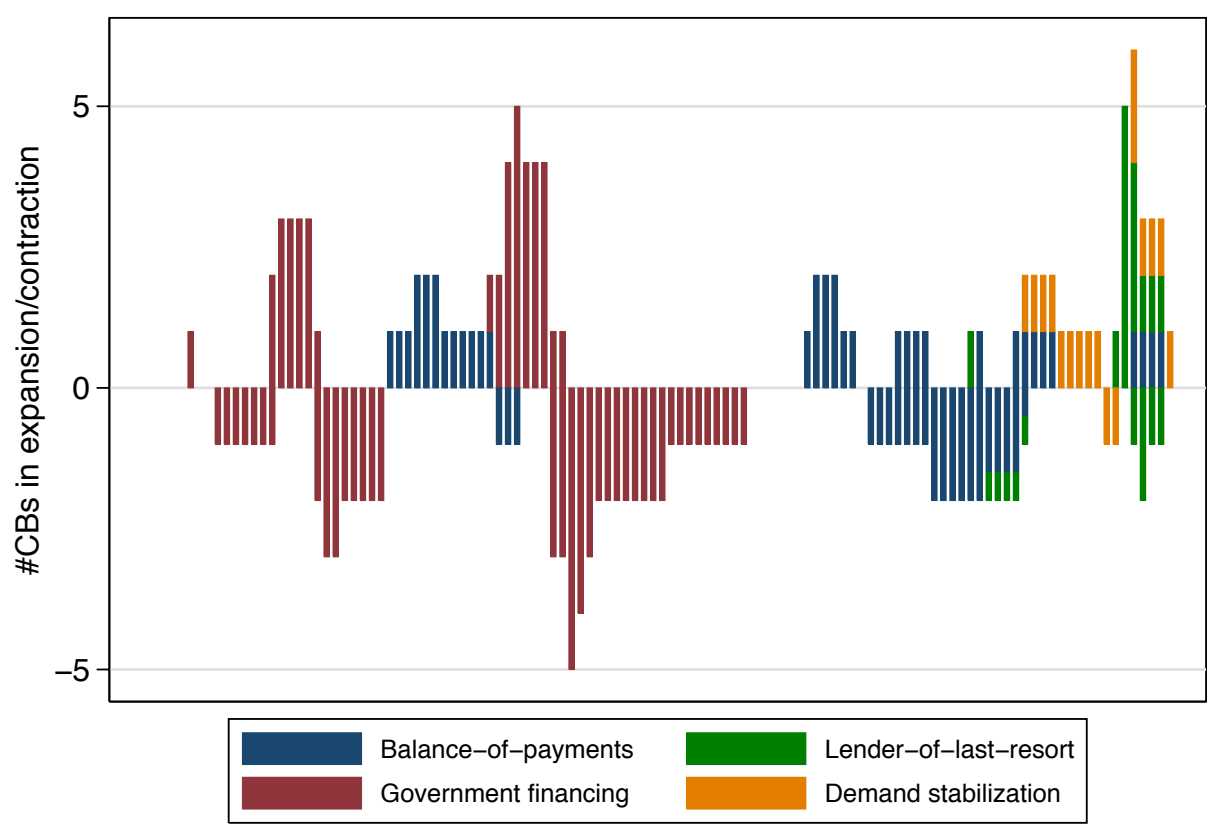

\section{The Federal Reserve After World War II}

As a result of World War II, the Federal Reserve System's balance sheet grew enormously: in nominal terms by a factor of 2.4 between 1939 and 1945 or 3.4 between 1938 and 1948. As Figure 12 makes clear, the increase was due largely to purchases of government securities - mainly Treasury Bills, which generally had 90-day maturities, and Treasury Certificates, which had maturities of up to a year.

What were the drivers of balance sheet expansion? The main answer is the policy of fixing interest rates. Unlike the Bank of England, the Federal Reserve System targeted long as well as short-term interest rates. Indeed, it began intervention in the market for Treasuries as early as September 1939 (Friedman and Schwartz 1963, p. 552). From April 1942 there was an explicit target for Treasury bills of three eighths of $1 \%$. Implicit targets were also observed for longer maturities. For long-term bonds the tacit ceiling was $2.5 \%$ (ibid., p. 563). The rationale was to avoid "disorderly conditions" in the government bond market (Mueller 1952). In effect, the Federal Reserve in wartime became "the bond-selling window of the Treasury" (Friedman and Schwartz 1963, p. 561), though it was also 
Figure 12: The Federal Reserve's government securities holdings, 1942 - 1956

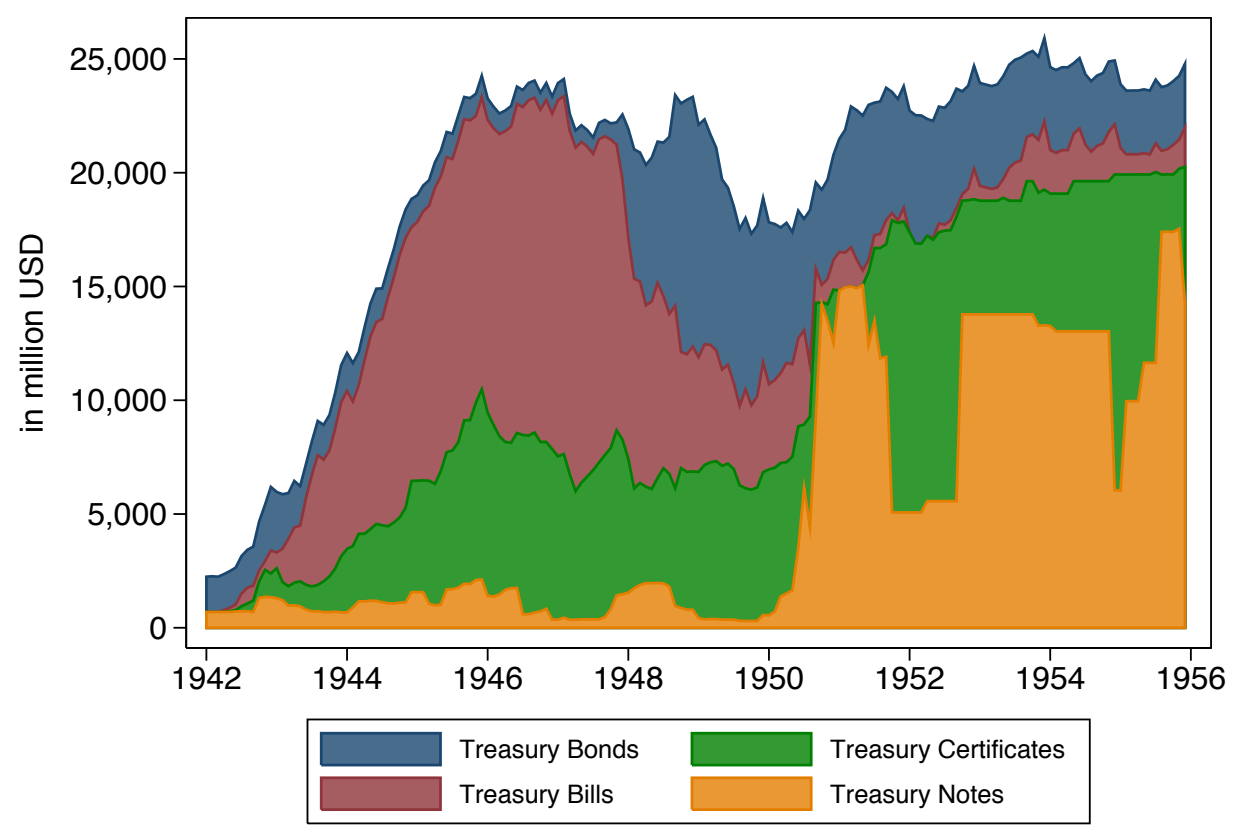

the bill-buying window - fixing rates meant selling or buying securities in whatever amounts the public wished to buy or sell at those rates. The rates were carried over from the late I930s and reflected the high liquidity preferences of the post-depression period; in wartime, with the Federal Reserve standing ready to buy or sell, the private sector preferred the higher yields on bonds to both bills and excess reserves. As a result the Federal Reserve ended up with hardly any long-term securities on its balance sheet. Such was public demand that, after 1943, yields fell some way below 2.5\%. A direct consequence of policy was a substantial increase of the money supply (the terminology is misleading, since the fixed rate policy converted all securities into the equivalent of money); in turn, the Federal Reserve "had no effective control over the quantity of high-powered money" (ibid., p. 566), i.e. the size of its own balance sheet.

Why was balance sheet expansion associated with lower inflation than in World War I (the consumer price index rose by just 2.3\% in 1945; inflation in 1918 had been an order of magnitude higher)? Various measures were taken to combat inflation. First, the Federal Reserve was empowered to impose controls on consumer credit. Second, reserve requirements were raised. At the same time, the federal government imposed price and wage controls between early 1942 and mid-1946 (these were briefly restored at the 
beginning of the Korean War). Of greater importance, however, was the fact that velocity declined sharply during the war (Friedman and Schwartz 1963, p. 558, p. 569). There was a "greater increase in willingness to save", which translated into very successful bond (War Loan) sales, culminating in the December 1945 Victory Loan (ibid., p. 571).

With the cessation of hostilities, however, the Federal Reserve was fearful of a surge of inflation - a fear augmented by large-scale inflows of gold and the termination of consumer credit controls (in November 1947, though they were temporarily restored between August 1948 and June 1949). Yet monetary policy did not change in any meaningful way: the Treasury Bill and certificate rates remained unchanged. (Changes in discount rates, increases in reserve requirements and a temporary increase in margin requirements on security purchases made little difference.) Not until July 1947, with wholesale prices surging, was the pegged rate on Treasury Bills scrapped; the rate on certificates was also unpegged the following month (Friedman and Schwartz 1963, p. 578f.). Yet when bond yields rose to $2.37 \%$ in November, the Federal Reserve joined the Treasury in a support action, buying USD 2 billion in bonds. Yields were allowed to rise to $2.45 \%$ in December, but from then until the end of 1948 they were again capped, with the Federal Reserve buying USD 3 billion in early 1948 (ibid., p. 579). These purchases were offset, it should be noted, by sales of short-term securities, so that the total Federal Reserve balance sheet grew more slowly in 1947 and 1948. It actually shrank in 1949, when the Federal Reserve went so far as to sell USD 3 billion of government bonds to counteract a temporary surge in bond prices. The official line remained that "disorderly conditions in the market for Government securities" were at all costs to be avoided (ibid., p. 621).

It is easy to forget that there was a time when such a policy was looked upon favourably by many economists. In a lecture delivered at Oxford in 1948, R.S. Sayers admiringly compared the Federal Reserve's post-war performance with the somewhat sorrier efforts of the Bank of England:

In the United States the Federal Reserve System has exercised a more direct and much more successful control over long-term interest rates than has the Bank of England. [...] The Federal Reserve System has stabilized a whole "pattern of rates", short-, mediumand long-term, by standing ready to enter any section of the market in protection of fixed rates. 
But Sayers aspired to more than "stable bond-market policy". In his view, the central bank "should [also] use financial controls to check [...] unhealthy developments in [...] particular directions". He looked admiringly at American regulation of trading margins and consumer credit:

Economic planning in a truly democratic society means pressing into service every conceivable device - persuading, cajoling, inciting people, edging the economy now a little in this direction, now a shade in that. If central banks are to play their full part in this process, our central bankers must not be content to stick to the traditional technique. (Sayers 1957, p. 25, p. 30, p. 34). In the words of Friedman and Schwartz, the experience of the Great Depression, the triumph of the Keynesian "revolution" in the academy, and the apparent success of wartime controls had persuaded many people like Sayers that "the stock of money adapted itself passively to economic changes" (Friedman and Schwartz 1963, p. 626). A more recent interpretation is that the Federal Reserve, scarred by the memory of the early 1930s, sincerely feared what falling bond prices would do to US banks (Eichengreen and Garber 1990). A third view is that the interest rate pegs were "a rough substitute for a commitment to return to a gold standard" (Hutchinson and Toma 1991).

What ended the period of bond yield targeting? There was no excessive growth in the balance sheet between 1946 and 1951, nor in the money supply (Lucia, 1975). On the other hand, inflation reached a peak above $20 \%$ in early 1947. According to Friedman and Schwartz, expectations changed. Prior to 1948, people had tended to assume that, as after World War I and as in the Great Depression, there would be a period of painful deflation (Friedman and Schwartz 1963, p. 585). "A changed pattern of anticipations" (ibid., p. 598) led to a rapid rise in velocity and, with it, an upsurge in prices. In particular, the Korean War "drastically altered public expectations about the near-term future and unleashed a speculative boom" (ibid., p. 610, p. 623; see also p. 674). Further alterations in expectations occurred when the 1953-54 recession proved "mild and brief" (ibid., p. 674; see also Meltzer 2010, p. 119).

It was fear of the inflationary consequences of continued pegging of the long-term yield that led to the breakdown of the wartime relationship between the Treasury and the Federal Reserve, which was no longer prepared to play the role of mere "window". The Federal Reserve dreaded having to monetise an avalanche of bond sales from non-bank 
entities, such as insurance companies. Another way of seeing this is as the collapse of a target zone which it was no longer necessary to maintain once the risks to banks of bond price normalisation had sufficiently diminished (Eichengreen and Garber 1990).

Hostilities between the Federal Reserve and the Treasury threatened to break out in August 1950, when the Board of Governors announced an open market policy designed to permit some rise in yields, though in the end the Federal Reserve bought most of the Fall 1950 refunding at a yield of $1.25 \%$ (Friedman and Schwartz 1963, p. 610). The Federal Reserve continued to support the Treasury's refunding operations, purchasing a substantial part of the five-year $1.75 \%$ note offered in exchange for maturing securities at the end of 1950, but its patience was wearing thin (ibid., p. 623).

As documented by Hetzel and Leach (2001), the struggle between the Federal Reserve and the Treasury in early 1951 posed a grave threat to the Federal Reserve's independence precisely because the White House sided so strongly with Treasury Secretary Snyder and because the outbreak of the Korean War seemed to justify a resumption of wartime methods. President Truman had a "mole" on the Federal Open Market Committee (FOMC), Governor James K. ("Jake") Vardaman, a friend from his Missouri days, who repeatedly leaked that body's deliberations to the White House and the press. The President himself directly warned the Chairman of the Board of Governors, Thomas B. McCabe: "I hope the Board will [...] not allow the bottom to drop from under our securities. If that happens that is exactly what Mr. Stalin wants". On January 31, 1951, the President summoned the entire FOMC to the White House to tell them: "[W]e must combat Communist influence on many fronts. [...] [I]f the people lose confidence in government securities all we hope to gain from our military mobilisation, and war if need be, might be jeopardised". The statements subsequently issued by the White House and the Treasury so grossly misrepresented the FOMC's position that Governor Marriner S. Eccles contradicted them in phone calls to journalists and then leaked the FOMC's own memorandum of the meeting with Truman.

Truman's fear that the Korean War might escalate into a Third World War was not without foundation. It was only by firing his commander in the field, MacArthur, that he could rule out the use of atomic bombs against China. Nevertheless, regardless of Armageddon, a majority of FOMC members believed that maintaining the cap on bond yields would have disastrous inflationary consequences because the public would respond 
to the prospect of another war by unloading their bonds on the Federal Reserve. In the words of Governor Eccles, it was the Federal Reserve that was making it "possible for the public to convert Government securities into money to expand the money supply. [...] We are almost solely responsible for this inflation [...] and this committee is the only agency in existence that can curb and stop the growth of money".

The published language of the final Treasury-Federal Reserve Accord, hammered out at the end of February, was deceptively simple: "The Treasury and the Federal Reserve system have reached full accord with respect to debt-management and monetary policies to be pursued in furthering their common purpose to assure the successful financing of the Government's requirements and, at the same time, to minimise monetisation of the public debt". What exactly did this mean? To some contemporaries, the Federal Reserve had won a "battle for survival [...] with the forces of the government" (Burgess 1954). Others believed the real winner was Congress (Haywood 1959). In reality, the final outcome was more a draw than a clear victory for anyone. Chairman McCabe was forced to resign; the man who replaced him was William McChesney Martin, Jr., the Assistant Secretary of the Treasury. Under the Accord's unpublished terms, to be sure, the Federal Reserve was relieved of its obligation to peg bond yields at $2.5 \%$. But it supported the March-April 1951 conversion of $2.5 \%$ bonds into $2.75 \%$ bonds and did not explicitly renounce bond price support for another two years (Friedman and Schwartz 1963, p. 613, p. 625), with the explicit adoption of the "bills only" doctrine. (There remained a statutory cap, dating back to 1918 , of $4.25 \%$ on the yield at issue of bonds with a maturity of more than five years, though market rates did not approach that level until 1959.) The discount rate was to be fixed until the end of 1951. Moreover, the Federal Reserve was still willing to intervene to support Treasury financings in July and September 1953, November 1955 and July 1958 (Haywood 1959). "How high", asked the economist Charles Haywood, "can the cost of servicing the Federal debt be pushed without impairing [the Federal Reserve's] political viability?".

As Federal Reserve Chairman, Martin believed not in independence as central bankers today define it, but in independence "within the government" (Meltzer 2010). The Federal Reserve retained responsibility for preventing new Treasury issues from failing. As Martin put it in 1950: "I do not believe it is consistent to have an agent so independent that it can undertake, if it chooses, to defeat the financing of a large deficit, which is a 
policy of the Congress". When the Federal Reserve bought bonds in July 1958 it was to counter a spike in yields occasioned by a crisis in the Middle East, which had led to the sending of US troops to Lebanon. As Martin observed in this connection: "The [FOM] Committee was dealing with the most difficult problem in political science in the whole world". (Meltzer 2010, p. 49)

So what exactly was Federal Reserve policy after the Accord? This is not an easy question to answer, not least because the new Chairman had a strong aversion to economic theory. According to Friedman and Schwartz, under Martin the Federal Reserve began paying attention to changes in the stock of money, though without explicitly targeting any growth rate. Recent research does not support this view. Insofar as there was a policy in the 1950s it was to target "free reserves" (excess reserves minus member bank borrowing), though there was seldom agreement on the FOMC about the target range. Martin preferred qualitative to quantifiable targets. He frequently spoke of "leaning against the wind" counter-cyclically, blithely ignoring the lags between actual turns in the business cycle and statistical evidence of them and often misinterpreting movements in market rates. It is conceivable that he did this deliberately, in the belief that to offer any kind of precise target would be to encourage the Federal Reserve's populist scourges in Congress to press for that target to be lowered (Meltzer 2010: p. 207n., p. 253).

Targeting free reserves meant, in practice, an eclectic mix of policies aimed at finetuning the money market. Having been raised in 1948 and lowered in 1949, reserve requirements were raised in 1951, then lowered in 1953, 1954, 1958, 1958 and 1960 (Friedman and Schwartz 1963: p. 602; Meltzer 2010). These changes were nearly always accompanied by offsetting changes in Federal Reserve credit outstanding (Friedman and Schwartz 1963: p. 604). i.e., purchases of Treasury Bills. The difference was that open market operations were not announced, whereas changes in reserve requirements were. The same was true of changes to the discount rate, the other policy lever frequently in use. Typical was Martin's performance in the summer of 1953, when he first talked in terms of tightening, and then reversed course when market rates rose further than he had anticipated (Friedman and Schwartz 1963, p. 613f.). Another favourite Martin phrase was the "even keel", which meant avoiding changes in free reserves for the two weeks surrounding Treasury debt operations (Meltzer 2010, p. 121).

The net result of policy was, by the standards of subsequent decades, by no means 
bad. Not only was overall growth strong, despite two recessions (1953- 54 and $1957-$ 58); inflation was also low (perhaps even negative if the contemporary index had been adjusted for quality improvements) and there was nothing resembling a financial crisis. The Federal Reserve's balance sheet was more or less stable in nominal terms and, as we have seen, shrank gently relative to GDP. How far this was a matter of luck rather than design is a matter of ongoing debate (Meltzer 2010, p. 90n.). Given the deficiencies of contemporary theory, it is tempting to emphasise the role of luck. Though theoretically constrained by the exchange rate rules of Bretton Woods, the Federal Reserve was in the more or less unique position of being able to ignore gold flows in its monetary policy (Friedman and Schwartz 1963, p. 636; Meltzer 2010, p. 79, p. 191). Moreover, the fundamental passivity of Martin's view of fiscal policy did not matter in the 1950s, as the federal government was running very small deficits or even surpluses. As one contemporary shrewdly observed:

Such short-run variations in the money supply as we have had were mainly pro-cyclical, a decline or a reduced rate of growth in the money supply occurring during recession and an accelerated growth during recovery. This raises some interesting questions, does it not? Does the Federal Reserve, in effect, laboriously contrive to bring about changes in credit conditions that, with a stable monetary system, would happen of their own accord? (Culbertson 1959) This verdict of mild pro-cyclicality has been endorsed by the Federal Reserve's most recent historian (Meltzer 2010, p. 33). The more serious criticism, however, is that the policies of the 1950s sowed the seeds - if only the intellectual seeds - of the "Great Inflation" of the 1970s (Meltzer 2010, p. 53).

\section{SOME Historical Lessons}

In this section, we bring together general observations and patterns that have emerged from our study of over a century of balance sheet data and ask to what extent they can provide historical guidance for what may lie ahead.

\subsection{Nominal Contractions are Rare}

The goal of this paper is to use history to contextualise recent balance sheet size expansions and to suggest some possible implications for policy normalisation in the years ahead. 
A natural question is therefore to ask is how central banks have historically achieved post-expansion balance sheet reductions.

A key finding is that only a few of the large balance sheet reductions in our sample were achieved by a nominal contraction in total assets. Instead, central banks generally normalised their balance sheet size over time as GDP grew simply by holding total assets stable for a while. Figure 13 plots averages across all contractions of both total assets and assets per GDP by year of contraction, where 1 denotes the first year of the contraction. On average, central banks held their balance sheet size relatively constant, and reductions were realised only in per-GDP terms. Figure 14 repeats this exercise for the reduction episodes after the World Wars only. In the aggregate, no contraction year exhibits a decline in nominal balance sheet size. These results are partly driven by the strong growth after World War II, which allowed central banks to achieve sizable reductions relative to GDP without shrinking their assets in nominal terms.

The exceptions to this overarching pattern are the reductions during the Nordic Crisis and after recent LLR policy measures, as well as the Bank of Japan's unwinding of its asset purchase programme in 2006. The balance sheet policies adopted by the Norges Bank and Sveriges Riksbank in 1986 and 1992, respectively, were primarily in response to external exchange rate pressure. The Norges Bank sterilised its FX intervention first through government security purchases and then bank lending. During the subsequent contraction period, the Norges Bank retained its holdings of longer-term bonds and instead unwound its position in shorter-term Treasury Notes almost fully within a year. In the Swedish case, Sveriges Riksbank's balance sheet size peaked in 1992 and declined in the next five years by over a third in nominal terms. By 1993 government security holdings accounted for over one third of the balance sheet. Sveriges Riksbank reduced this position by almost two thirds but did so gradually over a horizon of five years. 
Figure 13: Path of central bank balance sheet reductions*

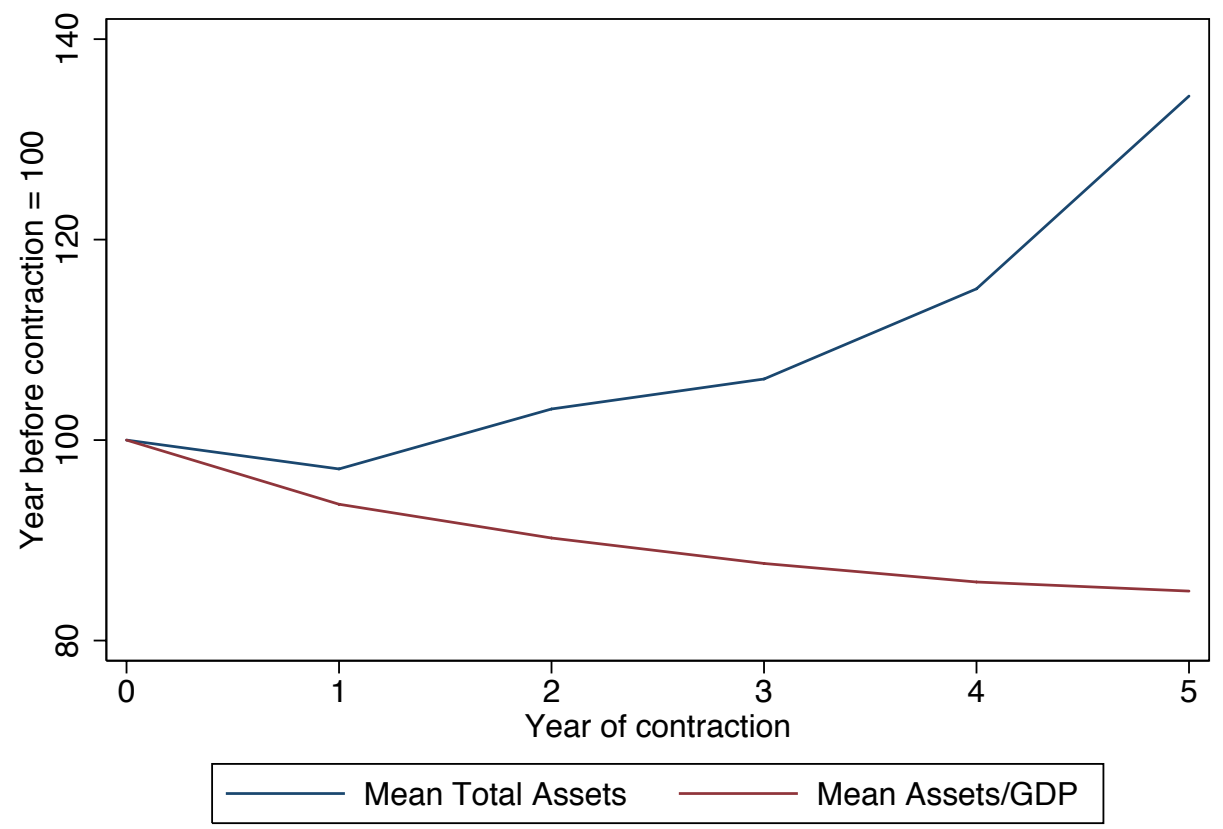

${ }^{*}$ Note: The year before the contraction is used as the base year and has the value of 100.

Figure 14: Path of central bank balance sheet reductions (after wars)*

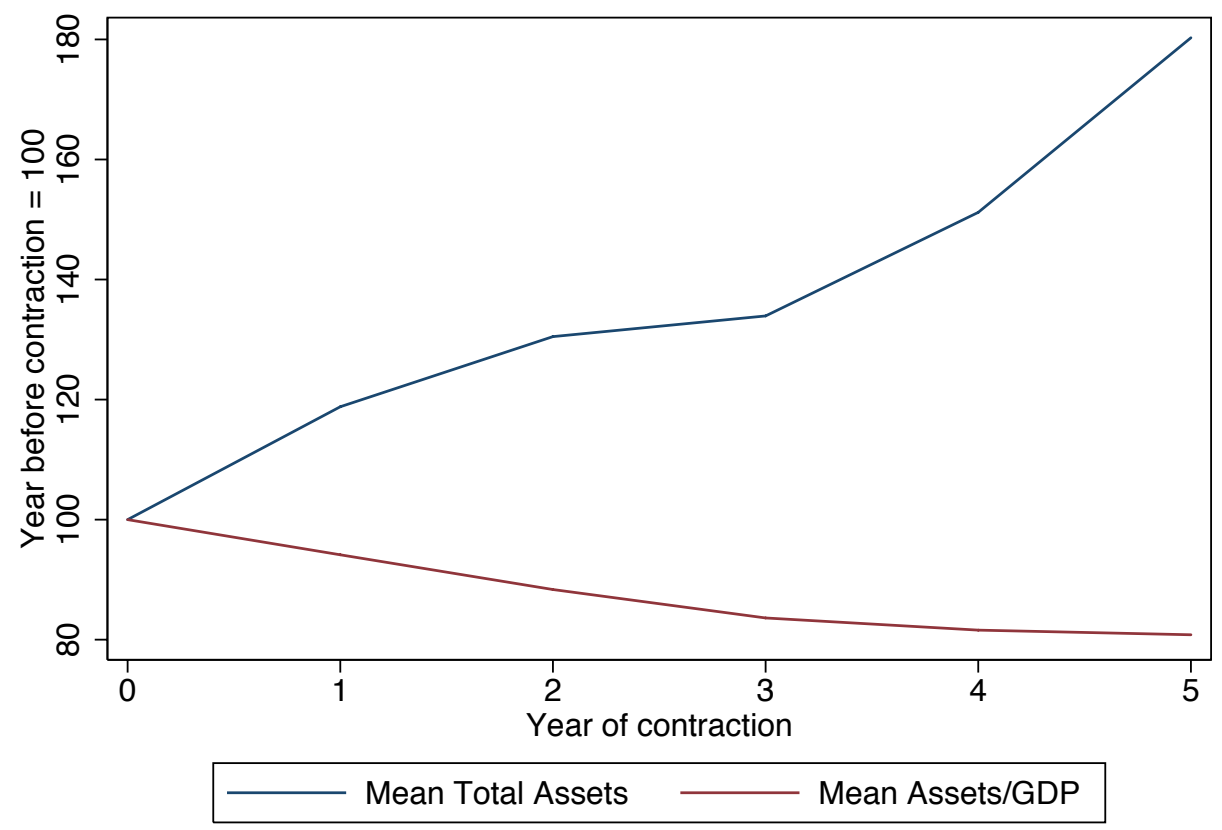


*Note: The year before the contraction is used as the base year and has the value of 100.

Historically, then, most major central banks have realised balance sheet reductions only relative to GDP rather than nominally. The few exceptions we have considered above suggest that, in cases where nominal downsizing was achieved, the maturity composition of the balance sheet was crucial. Over short time horizons, nominal reductions have occurred, if at all, primarily in positions that had short maturity and could easily be rolled off.

\subsection{Economic Conditions During Balance Sheet Contractions}

In the following, we provide crude but (we believe) not inadmissible evidence on the economic conditions in which central banks have pursued large-scale balance sheet contractions. In particular, we consider event windows around the start dates of such contraction episodes. The graphs that follow show the evolution of key economic variables in five-year windows before and after the start of the balance sheet contraction episodes. For this event study, we use the contraction episodes defined above. We then plot the deviation of key macro variables in the five years on either side of the contraction episode (excluding war years). Figure 15 plots the evolution of GDP per capita growth from its long-run trend; Figures $16-18$ then look at inflation, real bank lending and stock prices.

The first graph suggests that balance sheet reductions generally go hand in hand with slightly below trend growth around the beginning of the contraction and a small drag thereafter. While the mean estimate is negative for the first three years, the effects are not precisely estimated and the overall effect rather small. Nonetheless, there are some indications that large balance sheet reductions occur against the background of slightly lower real growth. Obviously, these conditional correlations cannot be interpreted in a causal sense.

Turning to inflation in Figure 16, we get the mostly intuitive result that inflation is above trend before the beginning of the contraction episodes and then falls back to trend-like levels or below. (Put differently, we cannot issue warnings about the risk of either inflation or deflation based on this admittedly crude event study.) There are, however, reasons to be concerned about the behaviour of bank lending during contraction episodes. As Figure 17 demonstrates, balance sheet reduction episodes have historically been associated with prolonged retrenchment of bank lending relative to trend. We think 
the persistent and relatively precisely estimated slowdown of bank lending relative to country-specific trends during central bank balance sheet contractions provides some cause for concern.

Last but not least, the development of equity markets comes as no surprise. Equity market performance turns sour a year before the beginning of the balance sheet reduction and remains subpar for most of the following years relative to long-run trends. Central bank balance sheet contraction episodes seem to take their toll on equity market performance. Caution is obviously warranted when interpreting these historical facts. Yet we find some indications that historically balance sheet reduction episodes have gone hand in hand with lower growth rates, somewhat lower inflation rates and substantial slowdowns in financial sector lending activity.

Figure 15: Real growth around balance sheet reductions

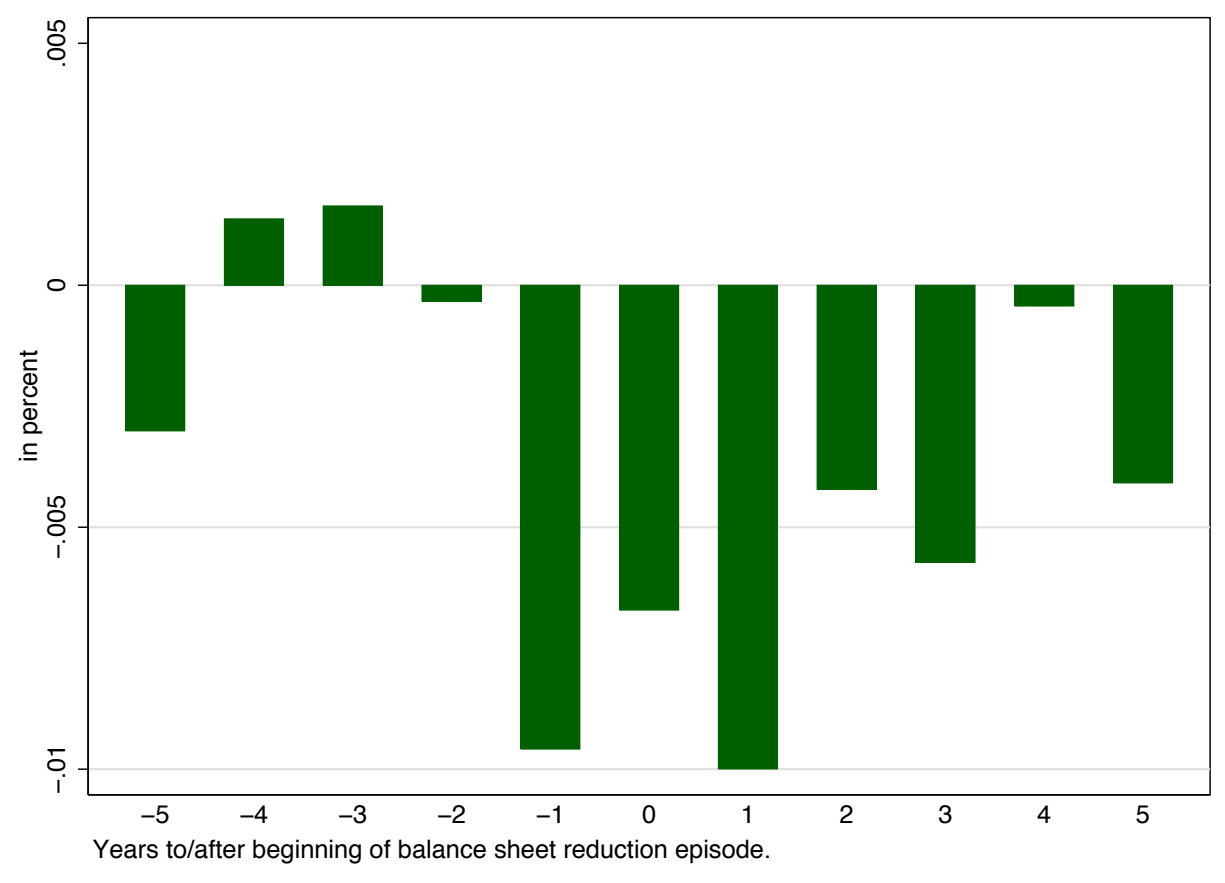


Figure 16: Inflation around balance sheet reductions

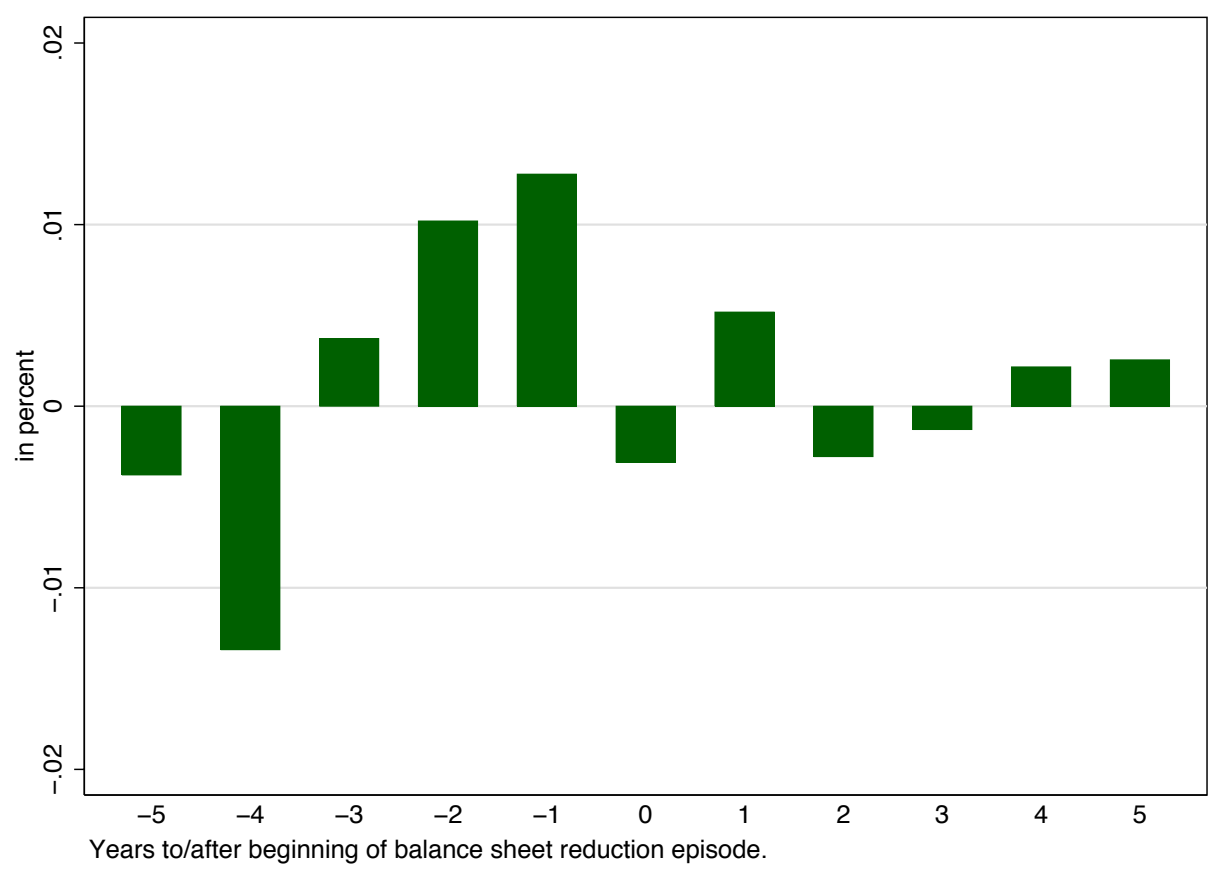

Figure 17: Real bank credit growth around balance sheet reductions

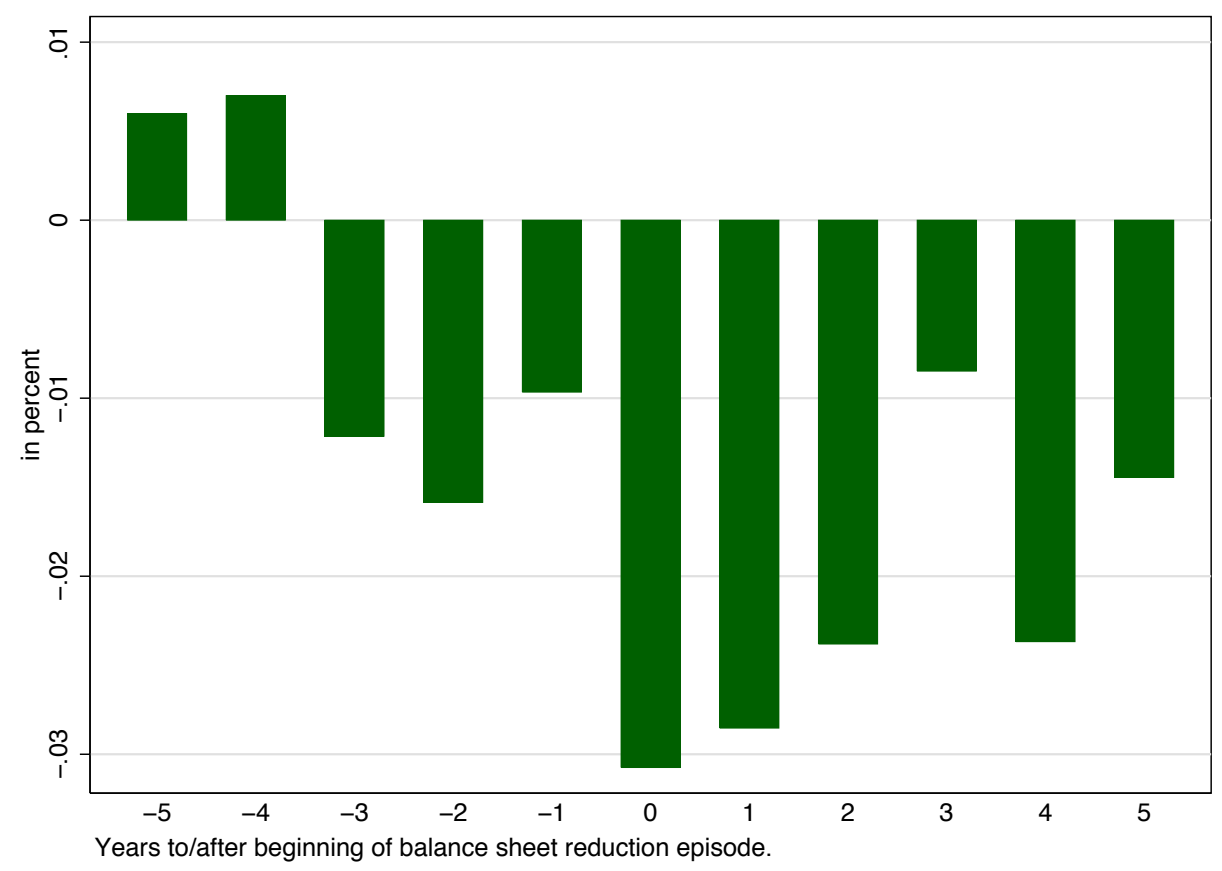


Figure 18: Real equity price growth around balance sheet reductions

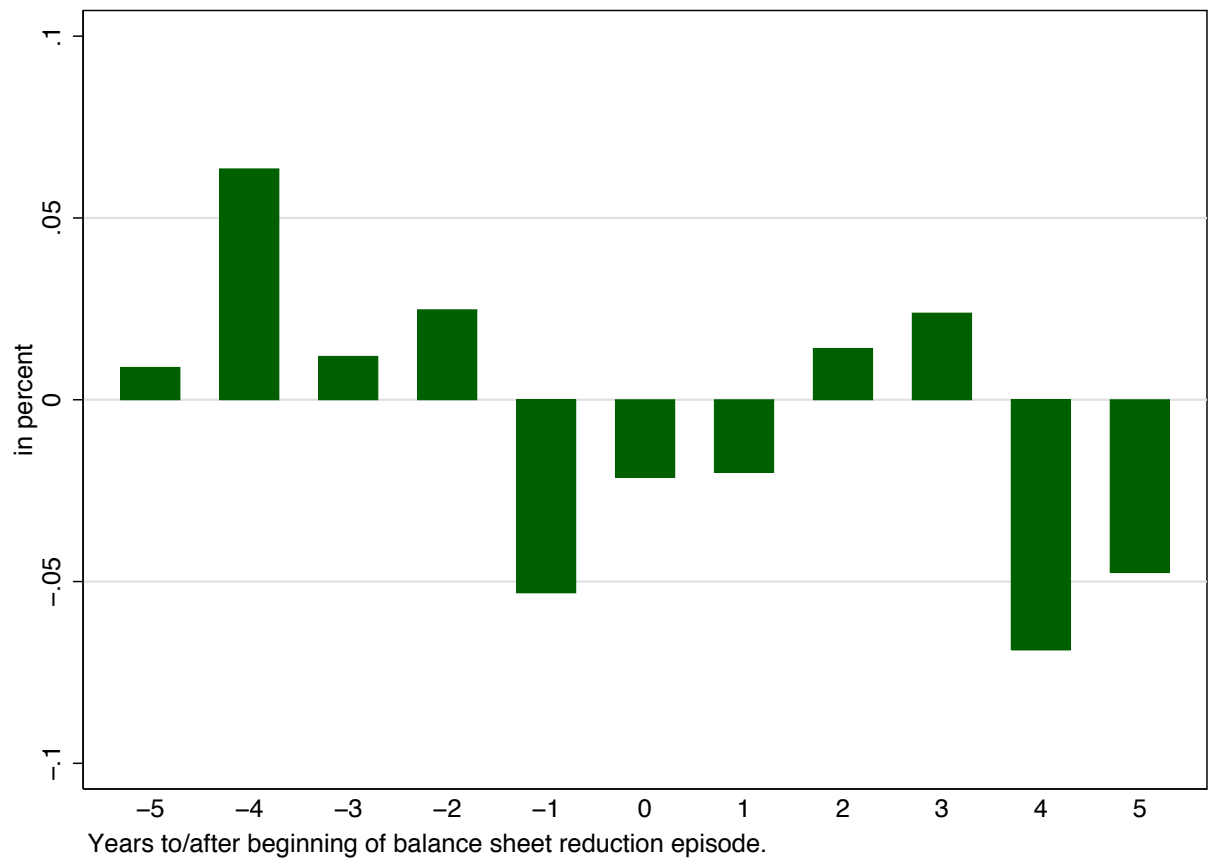

\section{Where Are We Now? In Search Of Historical Guidance}

In this concluding section, we ask how recent balance sheet size expansions compare historically with their predecessors. Recent work - e.g. Borio and Disyatat (2009) and D'Amico et al. (2012) - has already pointed out that, at least in the US case, the intent and instruments of post-2007 balance sheet policy have not been overly unconventional in kind. They have pointed out that central banks have adopted similar types of policies before. We will review their arguments below but begin by assessing what is plausibly the most unconventional aspect of recent central bank policies: their scale.

As we have pointed out in Section 3, the magnitude of balance sheet expansions during World War II still eclipses the recent episode in the aggregate. While the share of central banks undergoing large expansions was similar then and now, the magnitudes of expansion in those countries closest to the war were the largest in our sample. In both Norway and France, central bank balance sheet size relative to GDP changed by 75 percentage points during the war. We lack wartime GDP data for Germany, but it seems likely that the Reichsbank's balance sheet experienced a comparably large expansion. 
Some central banks have reached unprecedented levels since 2008, it is true. At the time of writing, the Federal Reserve's balance sheet size stands at approximately $25 \%$ of GDP, 3.5 percentage points higher than its previous record in 1946. The Bank of England had already broken through its 1946 record of $17.3 \%$ of GDP by the end of 2008, and recently stopped shy of $30 \%$ of GDP. The Bank of Japan's expansion after 1997, under its first asset purchase programme, failed to break through its 1944 balance sheet peak of $33.5 \%$ of GDP, reaching only $31 \%$ of GDP in 2005. But it did surpass its wartime peak in 2013. Relative to our full sample, however, neither the level at which these three central banks' balance sheets stand today relative to GDP nor the size of their expansions since 2008 has been altogether unprecedented. We record six episodes during which balance sheet size relative to GDP exceeded $40 \%$, and 25 episodes where it exceeded $25 \%$. Across our 23 large balance sheet expansions since 1900, four episodes exhibited a change in balance sheet size relative to GDP of over 30 percentage points, and 17 episodes saw changes above 15 percentage points. Relative to GDP, the Federal Reserve and the Bank of England have expanded their balance sheets by 18 and 25 percentage points, respectively, since 2007; the Bank of Japan has expanded its balance sheet by about 30 percentage points since 1997. Judged by the scale of recent balance sheet expansions, this time, as so often, is not so different.

What about intent? As we have seen, central bank balance sheets have experienced major expansions since 1900 for one (and sometimes more than one) of four reasons: balance of payments influences under fixed exchange rates, government financing (usually in wartime), lender of last resort and market functioning, and demand stabilisation. Since 2007, the last of these motives has played an important part in the operations of three of the major developed world central banks: the Bank of Japan, the Federal Reserve and the Bank of England. Others have primarily been engaged in lender of last resort operations. Even the aim of demand stabilisation was not wholly novel, however, as it had already been attempted by the Bank of Japan.

Borio and Disyatat (2009) have argued, with reference to the US and UK experiences, that the most unconventional features of recent balance sheet operations have been the market segments targeted under the Federal Reserve and Bank of England's large-scale asset purchase programmes. Conceptually, these measures have not been dissimilar to open market operations in that they aimed at changing interest rates and, through the 
transmission mechanism, borrowing rates. While "conventional" policy targets shortterm rates, recent balance sheet operations have primarily influenced the term premium component of long-term rates. What was different, these authors argue, was the range of securities bought: not only longer-term government bonds but also various private assets.

And yet, as D'Amico et al. (2012) among others point out, such operations would not have been deemed unconventional in the intellectual environment of the 1960s and 1970s, a time when preferred habitat theory came into vogue. The Federal Reserve experimented with them when it first increased its holdings of longer-term government bonds in line with Operation Twist and later even bought coupon issues of Fannie Mae and Freddie Mac, which, as government-guaranteed paper, were eligible for open market operations. And during World War II, as we have seen, the Federal Reserve sought to control "the whole pattern of rates".

Contemporary policy only appears "unconventional" because of the ascendancy of the expectations hypothesis after the 1980s, which declared central bank balance sheet operations to be ineffective from a theoretical standpoint. (Unlike in a preferred habitat setting, marginal changes in the central bank's portfolio could have no effects on asset prices under the assumptions of perfect arbitrage and asset substitution.) From a theoretical perspective, therefore, the concept of central bank asset purchases as a tool of policy is not novel, merely forgotten.

As noted above, there is a difference of intent between recent central bank balance sheet expansions and those of the period of World War II. The intent of large-scale asset purchases in our time has been to stabilise aggregate demand. The intent in the 1940s was to assist the national Treasury with paying for the war. The instruments purchased in wartime were almost exclusively government bonds and bills; since 2007, the Federal Reserve in particular has also purchased securities issued by private sector entities. Yet, whatever the intent of a central bank, the effects of its actions may not differ so very much as between war and peace. Large-scale asset purchases have implications for government finance, even when government finance is not the primary objective of the purchases, because depressing bond yields reduces government debt service costs, especially when the public debt is relatively high. Consequently, efforts to normalise rates may give rise to frictions between monetary and fiscal authorities, as happened in the early 1950 .

As then, the Federal Reserve may find itself under political pressure from the Treasury, 
White House or Congress if the policies it wishes to pursue clash with the exigencies of debt management or are seen to harm the interests of influential constituents. As then, the Federal Reserve may have to contend with unexpected changes in expectations, instigated by "out of model" geopolitical events. As then, the Federal Reserve now has a rather eclectic monetary theory, which includes relative indifference to international capital flows and a confidence in the dollar's supremacy as the international reserve currency, as well as a readiness to consider (if not to target) an ever widening range of indicators. And, as then, the Federal Reserve may have recourse to instruments of credit control that fell into disuse in the intervening years (Reinhart and Rogoff 2013).

\section{CONCLUSIONS}

In this paper, we have presented a new dataset on historical central bank balance sheet fluctuations that we have assembled from a wide array of historical sources. Our key goal was to present the facts about large balance sheet expansion and contraction episodes, in order to contextualise what may lie ahead, in the belief that financial history can provide a valuable corrective to the amnesia of economic theory.

We have shown, firstly, that in most developed countries since 1900, balance sheet size relative to output has fluctuated within rather clearly defined bands most of the time. The exceptions are clusters of big expansions and contractions associated with periods of geopolitical or financial crisis. The biggest of these crises, in terms of their impact on central bank balance sheets, were World War II and the recent financial crisis. Measured both by scale and incidence, the post-2007 expansion episode has eclipsed all other historical precedents. Secondly, we have shown that, over the sample period, central bank balance sheet size and public debt relative to GDP have exhibited a surprisingly high degree of co-movement, along with the series "government debt securities held by the central bank". This observation holds particularly strongly for the period during and after the World Wars. During periods of major economic and political pressure, the fiscal and monetary authorities have tended to work in concert. We believe this has important implications for some major central banks today.

Thirdly, with a few exceptions, large balance sheet expansions have on average taken a long time to unwind. The post-war balance sheet contractions were especially protracted, 
extending in some countries from the late 1940s to the late 1960s.

A fourth historical lesson we draw is that central banks rarely reduce the size of their balance sheets in nominal terms after large expansion episodes. Reductions are predominantly achieved in real terms by holding nominal positions stable for some time - this is particularly true for post-war reductions. Important exceptions to this finding are more recent balance sheet expansions related to lender of last resort measures and exchange rate interventions. In these cases, balance sheet composition - in particular the maturity of assets - has been an important determinant of how central banks achieved balance sheet reductions. On the basis of the evidence presented here, it would not be unreasonable to expect the contraction of central bank balance sheets, when it finally comes, to be protracted and to take place relative to GDP rather than nominally. It will happen faster where central bank assets have a shorter average maturity. Our fifth finding is that, relative to the size of the financial sector, central bank balance sheets had shrunk dramatically in the three decades preceding the global financial crisis. By that yardstick, their recent expansion merely marks a return to earlier levels. Another insight from financial history is that some of the recent increase could prove to be permanent if the financial sector is expected to maintain higher liquidity ratios.

Finally, the near-term inflation risks from the recent balance sheet expansion appear limited because the link between central bank balance sheet growth and inflation has loosened considerably in most advanced economies since 1980. There is, however, an important caveat that we infer from the experience of the 1950s. An important lesson of that period is that fiscal considerations are not easy to ignore once a central bank has involved itself in keeping long-term interest rates low, for to "normalise" rates is to increase debt servicing costs, as well as to reverse the other distributional consequences of large-scale asset purchases. So long as the credibility of central banks as independent custodians of price stability remains intact, balance sheet expansions need not be inflationary, even if in nominal terms they become permanent. But history suggests that the threat to long-run price stability is a real if slow-acting one when fiscal deficits are persistent and central bank independence is compromised. 


\section{A. Data Coverage by Country}

Australia: The Reserve Bank of Australia was founded in 1960, after the 1959 Reserve Bank Act removed the monetary authority from the Commonwealth Bank. The Commonwealth Bank, in turn, acted as Australia's central bank between 1920 and 1960, assuming this responsibility gradually after 1920. We use balance sheet data for the Commonwealth Bank from 1920 to 1945, and from 1950 to 1959. We use balance sheet data for the RBA thereafter. We have no data between 1946 and 1949. Foreign assets are missing for the period after 1950, foreign liabilities are missing for the whole period. Notes in circulation and bank deposits are missing before 1950. Canada: The Bank of Canada was established in 1934 and we have data starting from 1935. Data for gold holdings are missing for the whole period. Data on foreign asset holdings are missing after 1980, those for foreign liabilities before 1945 and after 2004 .

Switzerland: The Swiss National Bank was established in 1907 and we have data since then. Government debt is missing for the whole period, foreign liability holdings are missing before 1961 .

Germany: We have data for the Reichsbank between 1900 and 1944, for the Bank deutscher Länder between 1948, the year it was established, and 1956, and for the Bundesbank between 1957 and 2011. Our data for the Reichsbank are missing foreign assets and liabilities holdings, as well as government debt. We have no data for bank deposits for the Bank deutscher Lnder. Foreign liabilities are missing after 1998.

Finland: The Bank of Finland was established in 1812. We have full data coverage from 1900 onwards, except for foreign assets, which are missing before 1999.

France: We have data coverage for the Banque de France from 1900 onwards. The foreign liabilities and bank deposits positions are missing for the whole period. We have no data for the year 1941, and between 1974 and 1977. Foreign assets and government debt are also missing between 1978 and 1994 . 
Italy: Banca d'Italia was established in 1893 and began issuing bank notes in 1926. We have no data for the year 1939 due to a change in account reporting. Data for 1938 are reports as of December, data for 1940 are reported as of June of that year. We have no data on gold before 1936, on foreign liabilities before 1936, on government debt between 1936 and 1964, and on total deposits between 1936 and 1964. We have no data coverage of bank deposits before 1999, and the foreign assets position is missing between 1965 and 1998.

Japan: The Bank of Japan was founded in 1871. We have no data for foreign liabilities, for foreign assets before 1906, and between 1941 and 1969. We have no coverage of gold holdings between 1941 and 1997, and for bank deposits between 1966 and 1997.

Norway: The Norges Bank was established in 1816. We lack coverage for 1945, and for the bank deposits position over the whole period. We have no data for foreign liabilities before 1950 and between 1989 and 1991, and for foreign assets between 1978 and 1984. Gold holdings are missing from 1992 to 2003. The Norges Bank transferred its government debt holdings to the Treasury in 2004, so we have a position of zero holdings thereafter.

Sweden: Sveriges Riksbank was founded in 1688. We have no coverage of government debt before 1920 and after 2001. We are missing foreign liabilities holdings from 1943 to 1976, and we lack data on total deposits after 1998. United Kingdom: The Bank of England was established in 1694. We have data coverage for all positions except foreign assets and foreign liabilities, with bank deposits missing before 1962.

United States: The Federal Reserve was established in 1913. Our data coverage begins in 1914. The foreign assets position is almost completely missing, and gold is missing after 1945 .

We summarise coverage for our macro variables in the following two tables: 
Table 5

\begin{tabular}{|l|ccccccccc|}
\hline & Money & $\begin{array}{c}\text { Narrow } \\
\text { money }\end{array}$ & GDP & $\begin{array}{c}\text { Capital } \\
\text { formation/GDP }\end{array}$ & CPI & Population & Stocks & Debt/GDP & $\begin{array}{c}\text { Total } \\
\text { loans }\end{array}$ \\
\hline AUS & 112 & 112 & 103 & 110 & 112 & 112 & 112 & 112 & 110 \\
CAN & 103 & 104 & 103 & 110 & 112 & 112 & 97 & 112 & 111 \\
CHE & 112 & 108 & 112 & 77 & 112 & 112 & 101 & 93 & 112 \\
DEU & 89 & 90 & 90 & 101 & 107 & 112 & 112 & 104 & 99 \\
FIN & 112 & 112 & 112 & 112 & 112 & 112 & 90 & 95 & 112 \\
FRA & 98 & 103 & 95 & 103 & 112 & 112 & 112 & 96 & 105 \\
ITA & 103 & 102 & 112 & 112 & 112 & 112 & 106 & 111 & 112 \\
JPN & 96 & 102 & 104 & 110 & 104 & 112 & 99 & 109 & 107 \\
NOR & 111 & 111 & 106 & 106 & 112 & 112 & 97 & 105 & 111 \\
SWE & 112 & 112 & 101 & 112 & 112 & 112 & 112 & 104 & 112 \\
UK & 112 & 112 & 112 & 112 & 112 & 112 & 112 & 112 & 112 \\
US & 112 & 109 & 112 & 112 & 112 & 112 & 112 & 112 & 112 \\
\hline Total & 1272 & 1277 & 1262 & 1277 & 1331 & 1344 & 1262 & 1265 & 1315 \\
\hline
\end{tabular}


Table 6

\begin{tabular}{|l|ccccccc|}
\hline & $\begin{array}{c}\text { Short-term } \\
\text { rate }\end{array}$ & $\begin{array}{c}\text { Long-term } \\
\text { rate }\end{array}$ & Gov revenue & $\begin{array}{c}\text { Gov tex } \\
\text { revenue }\end{array}$ & $\begin{array}{c}\text { Gov } \\
\text { expenditure }\end{array}$ & FX & Peg \\
\hline AUS & 73 & 112 & 111 & 111 & 111 & 112 & 112 \\
CAN & 67 & 112 & 111 & 111 & 111 & 112 & 112 \\
CHE & 111 & 110 & 112 & 111 & 112 & 112 & 112 \\
DEU & 102 & 109 & 92 & 93 & 90 & 112 & 112 \\
FIN & 112 & 89 & 112 & 112 & 112 & 112 & 112 \\
FRA & 96 & 112 & 112 & 112 & 112 & 112 & 112 \\
ITA & 105 & 112 & 112 & 112 & 112 & 112 & 112 \\
JPN & 94 & 101 & 110 & 111 & 105 & 112 & 112 \\
NOR & 100 & 112 & 107 & 112 & 112 & 112 & 112 \\
SWE & 112 & 112 & 112 & 112 & 112 & 112 & 112 \\
UK & 112 & 112 & 112 & 112 & 112 & 112 & 112 \\
US & 110 & 112 & 112 & 112 & 112 & 112 & 112 \\
\hline Total & 1194 & 1305 & 1315 & 1321 & 1313 & 1344 & 1344 \\
\hline
\end{tabular}




\section{REFERENCES}

Admati, A.R., and Hellwig, M.F. (2013) The Bankers' New Clothes: What's Wrong with Banking and What to Do about It, Princeton University Press, Princeton, NJ.

Aikman, D., Haldane, A.G. and Nelson, B.D. (2014) Curbing the Credit Cycle, The Economic Journal, forthcoming.

Bernanke, B.S. and Reinhart, V.R. (2004) Conducting Monetary Policy at Very Low Short-Term Interest Rates, American Economic Review, 94(2), 85-90.

Borio, C. and Disyatat, P. (2009) Unconventional Monetary Policies: An Appraisal, BIS Working Papers, No 292, November.

Burgess, W.R. (1954) Federal Reserve and Treasury Relations, Journal of Finance, 9(1), March, 1-11.

Culbertson, J.M. (1959) Timing Changes in Monetary Policy, Journal of Finance, 14(2), May, 145-160.

D'Amico, S., English, W., Lopez-Salido, D. and Nelson, E. (2012) The Federal Reserve's Large-Scale Asset Purchase Programmes: Rationale And Effects, The Economic Journal, 122, November, 415-446.

Eichengreen, B. and Garber, P. (1990) Before The Accord: U.S. Monetary-Financial Policy 1945-51, NBER Working Paper, No 3380, June.

Goodfriend, M. (2011) Central Banking in the Credit Turmoil: An Assessment of Federal Reserve Practice, Journal of Monetary Economics, 58, 1-12.

Greenwood, R. and Scharfstein, D. (2013) The Growth of Finance, Journal of Economic Perspectives, 27(2), 3-28.

Haywood, C.F. (1959) The Adequacy of Federal Reserve Powers to Discharge Responsibilities, Journal of Finance, 14(2), May, 135-144.

Hetzel, R.L. and Leach, R.F. (2001) The Treasury-Fed Accord: A New Narrative Account, Federal Reserve Bank of Richmond Economic Quarterly, 87(1), winter, 33-55.

Hutchinson, W.K. and Toma, M. (1991) The Bond Price Support Program as a Change in Policy Regimes: Evidence From The Term Structure of Interest Rates, Journal of Money, Credit and Banking, 23(3), August, 367-382.

Friedman, M. and Schwartz, A.J. (1963) A Monetary History of the United States, 18671960, Princeton University Press, Princeton, NJ. 
International Monetary Fund (2013) Global Impact and Challenges of Unconventional Monetary Policies, IMF Policy Paper, 7 October.

Jordà, Ò., Schularick, M. and Taylor, A. (2013) Sovereigns versus Banks: Credit, Crises, and Consequences, NBER Working Paper, No 19506, October.

Jordà, Ò., Schularick, M. and Taylor, A. (2013) When Credit Bites Back, Journal of Money, Credit and Banking, 45: 3-28.

Jordà, Ò., Schularick, M. and Taylor, A. (2014) The Great Mortgaging: Housing Finance, Crises, and Business Cycles. National Bureau of Economic Research, No 20501.

Kliem, M., Kriwoluzky, A. and Sarferaz, S. (2013) On the low-frequency relationship between public deficits and inflation, Deutsche Bundesbank Discussion Papers, No 12.

Krishnamurthy, A. and Vissing-Jorgensen, A. (2013) The Ins and Outs of LSAPs, Global Dimensions of Unconventional Monetary Policy, Federal Reserve Bank of Kansas City Economic Policy Symposium 22-24 August 2013, Jackson Hole, Wyoming, September.

Krogstrup, S., Reynard, S. and Sutter, B. (2012) Liquidity Effects of Quantitative Easing on Long-Term Interest Rates, Swiss National Bank working paper, January.

Lucas, R.E., Jr. (1980) Two Illustrations of the Quantity Theory of Money, American Economic Review, 70(5), December, 1005-1014.

Lucia, J.L. (1975) A Reevaluation of U.S. Monetary Policy in the Pre-Accord Period, Nebraska Journal of Economics and Business, 14(4), autumn, 21-31.

McLeay, M., Radia, A. and Thomas, R. (2014a) Money in the Modern Economy: An Introduction, Bank of England Quarterly Bulletin, 54(1), 1-10.

McLeay, M., Radia, A. and Thomas, R. (2014b) Money Creation in the Modern Economy, Bank of England Quarterly Bulletin, Vol. 54, No 1, pp. 14-27.

Meltzer, A.H. (2010) A History of the Federal Reserve, Volume 2, Book 1, 1951-1969, University of Chicago Press, Chicago.

Mueller, F.W., Jr. (1952) The Treasury-Federal Reserve Accord, Journal of Finance, 7(4), December, 580-599.

Philippon, T. (2012) Has the US finance industry become less efficient? On the theory and measurement of financial intermediation, NBER Working Paper, No 18077.

Philippon, T. and Reshef, A. (2013) An international look at the growth of modern finance, Journal of Economic Perspectives, 27(2), 73-96.

Reynard, S. (2006) Money and the Great Disflation, Swiss National Bank working paper, 
January.

Reynard, S. (2012), Assessing Potential Inflation Consequences of QE after Financial Crises, Peterson Institute for International Economics Working Paper, November,12-22.

Reinhart, C.M. and Rogoff, K.S. (2013) Shifting Mandates: The Federal Reserve's First Centennial, American Economic Review: Papers E Proceedings, 103(3), 48-54.

Sargent, T.J. and Surico, P. (2011) Two Illustrations of the Quantity Theory of Money:

Breakdowns and Revivals, American Economic Review, 101, February, 109-128.

Sayers, R.S. (1957), Central Banking after Bagehot, Clarendon Press, Oxford.

Schularick, M. and Taylor, A. (2012) Credit Booms Gone Bust: Monetary Policy, Leverage

Cycles, and Financial Crises, American Economic Review, 102(2), 1029-1061.

Stone, M., Fujita, K. and Ishi, K. (2011) Should Unconventional Balance Sheet Policies be Added to the Central Bank Toolkit? A Review of the Experience So Far, IMF Working Paper, No 11/145, June. 